\title{
Profile of World Uranium Enrichment Programs - 2007
}

November 2007

Prepared by

M. D. Laughter

Nuclear Science and Technology Division 


\section{DISCLAIMER}

This report was prepared as an account of work sponsored by an agency of the United States Government. Neither the United States Government nor any agency thereof, nor any of their employees, makes any warranty, express or implied, or assumes any legal liability or responsibility for the accuracy, completeness, or usefulness of any information, apparatus, product, or process disclosed, or represents that its use would not infringe privately-owned rights. Reference herein to any specific commercial product, process, or service by trade name, trademark, manufacturer, or otherwise, does not necessarily constitute or imply its endorsement, recommendation, or favoring by the United States Government or any agency thereof. The views and opinions of authors expressed herein do not necessarily state or reflect those of the Unites States Government or any agency thereof. 
Nuclear Science and Technology Division

Safeguards Group

\title{
PROFILE OF WORLD URANIUM ENRICHMENT PROGRAMS - 2007
}

\author{
M. D. Laughter
}

ORAU/ORNL

Date Published: November 2007

This work supported by the

National Nuclear Security Administration

Office of Nonproliferation and International Security - NA-24

Prepared by

OAK RIDGE NATIONAL LABORATORY

Oak Ridge, Tennessee 37831-6254

managed by

UT-BATTELLE, LLC

for the

U.S. DEPARTMENT OF ENERGY

under contract DE-AC05-00OR22725 



\section{CONTENTS}

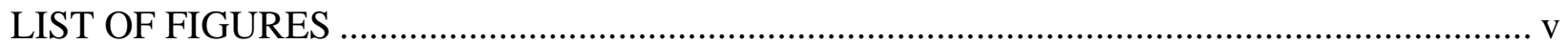

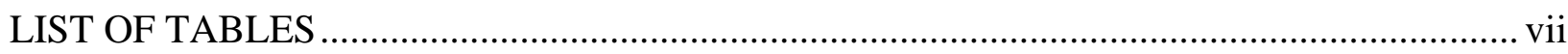

ACRONYMS AND ABBREVIATIONS ....................................................................... ix

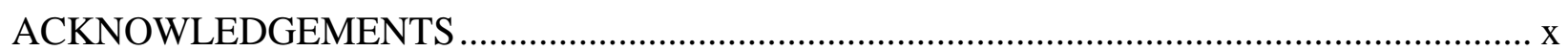

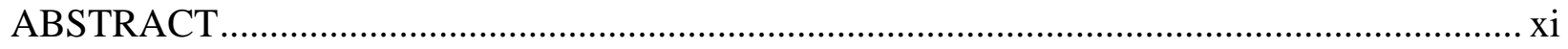

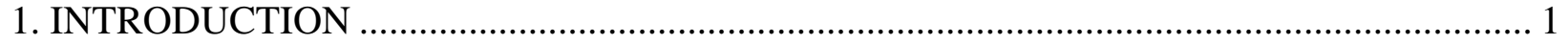

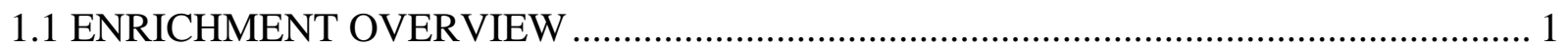

1.2 WORLD ENRICHMENT CAPACITY ....................................................................... 1

1.3 THE HEXAPARTITE SAFEGUARDS PROJECT ....................................................... 3

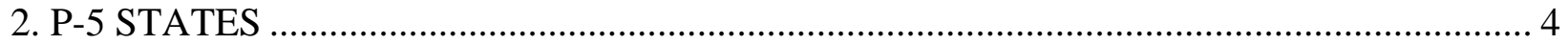

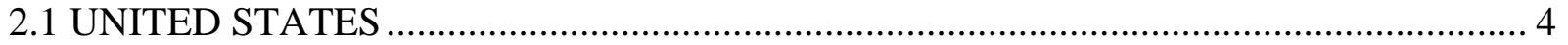

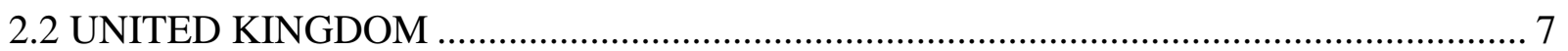

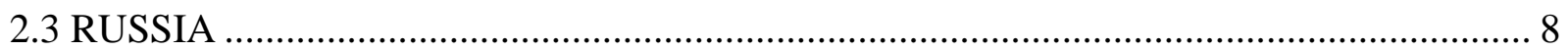

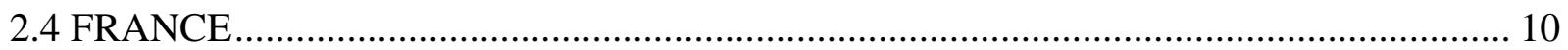

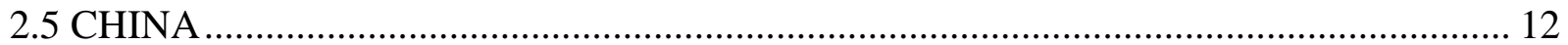

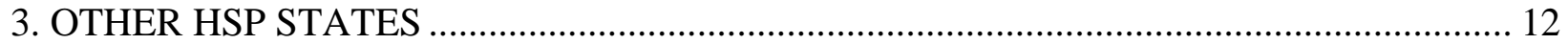

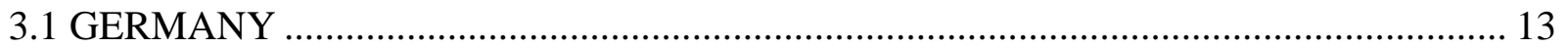

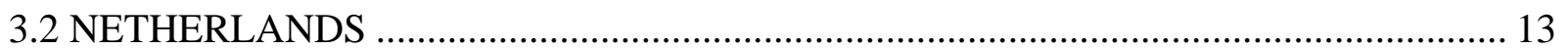

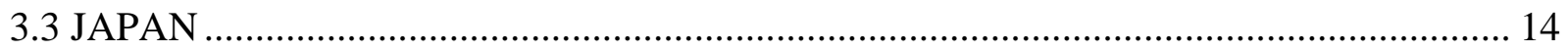

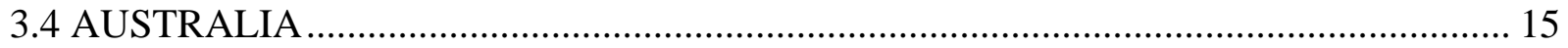

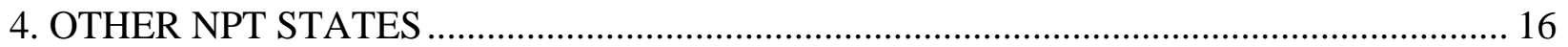

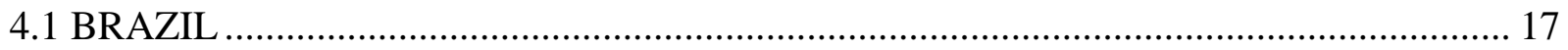

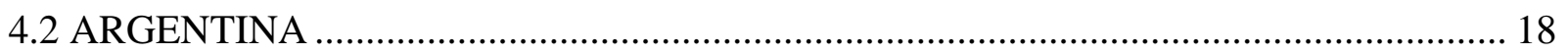

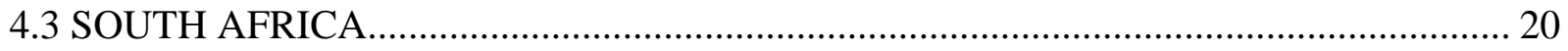

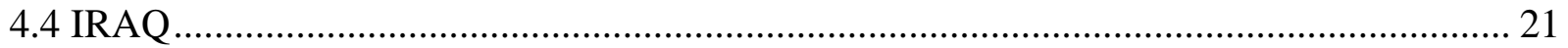

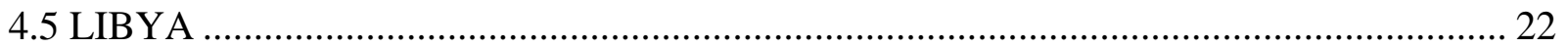

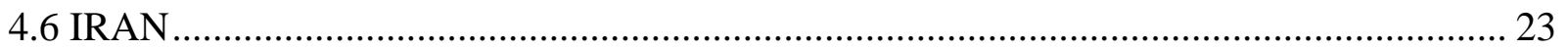

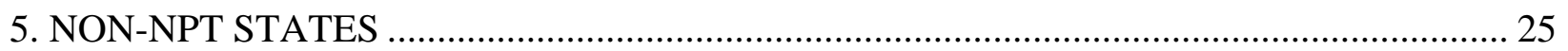

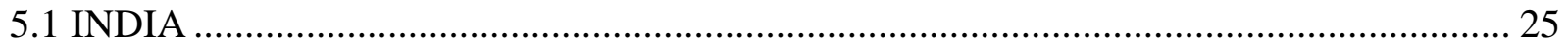

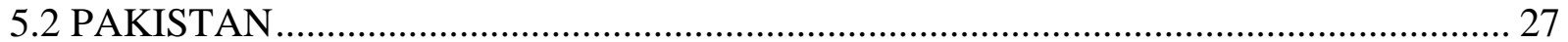

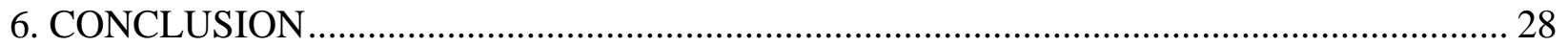

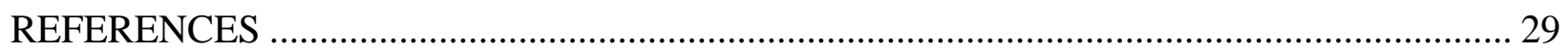





\section{LIST OF FIGURES}

Figure

1. Alpha Calutron track, Y-12 Plant, United States ............................................................. 4

2. K-25 building at the Oak Ridge GDP, United States..................................................... 5

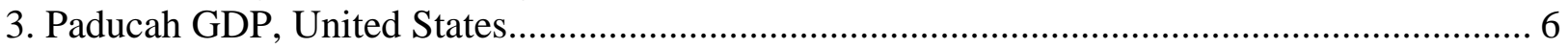

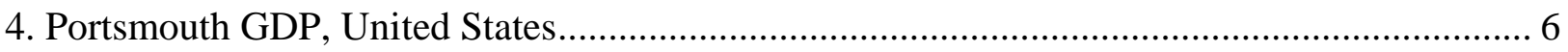

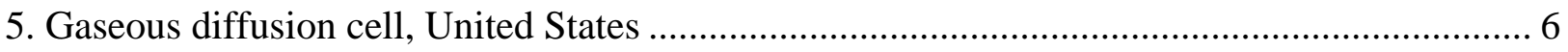

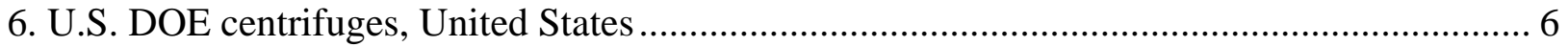

7. National Enrichment Facility visual model, United States ................................................. 6

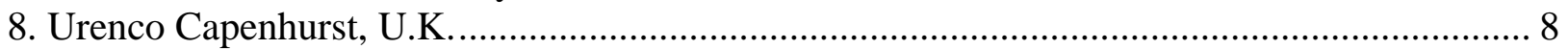

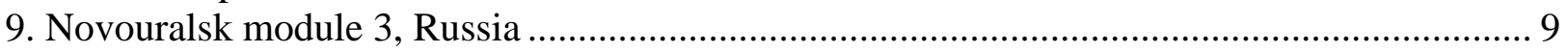

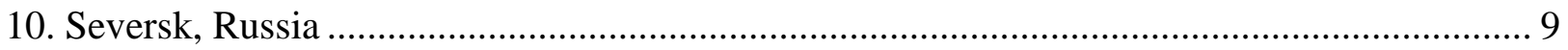

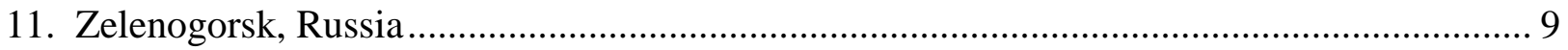

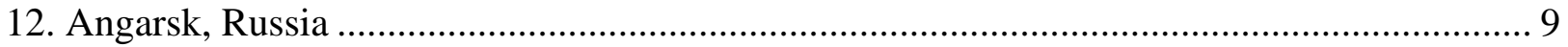

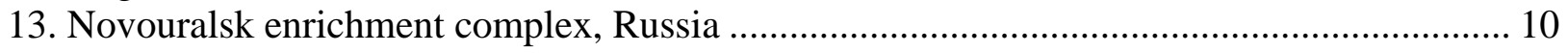

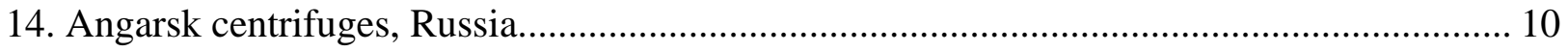

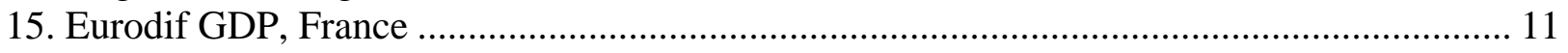

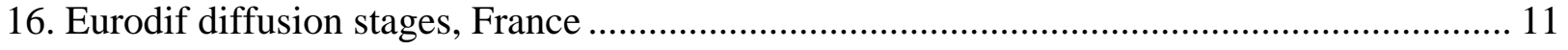

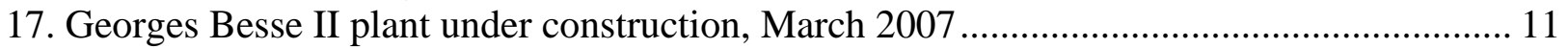

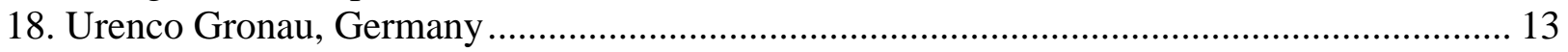

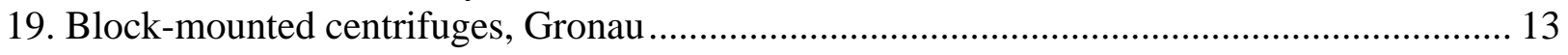

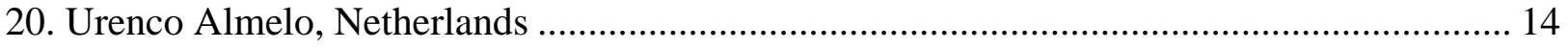

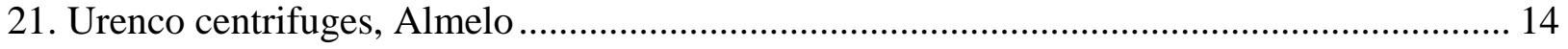

22. Rokkasho Uranium Enrichment Plant, Japan ............................................................ 14

23. Lucas Heights Science and Technology Centre, Australia ............................................... 16

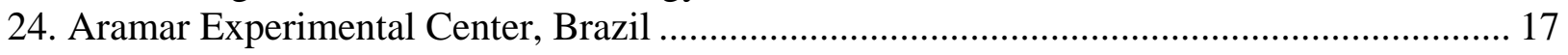

25. Resende Nuclear Fuel Facility, Brazil ..................................................................... 18

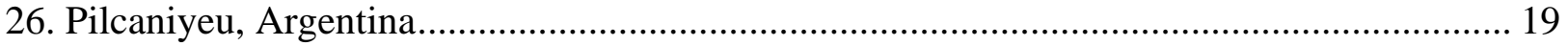

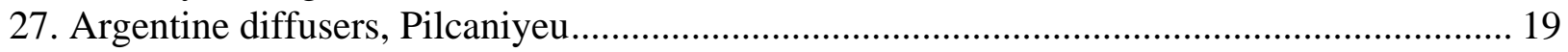

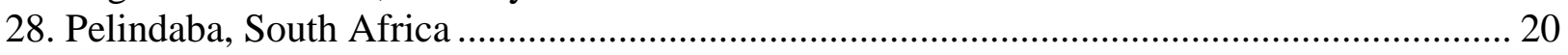

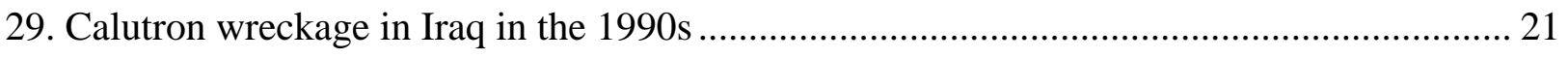

30. Centrifuges discovered in Iraq by IAEA inspectors in the 1990s..................................... 22

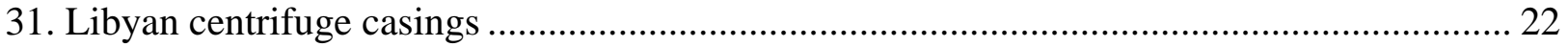

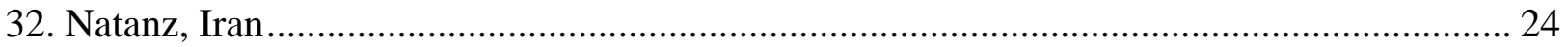

33. The 164-centrifuge cascade at the Natanz PFEP, Iran...................................................... 24

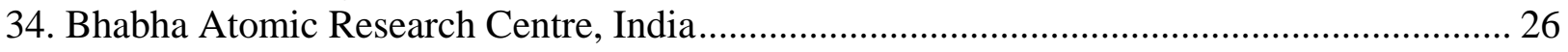

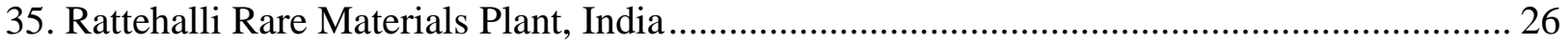

36. Khan Research Laboratory, Kahuta, Pakistan ............................................................ 27

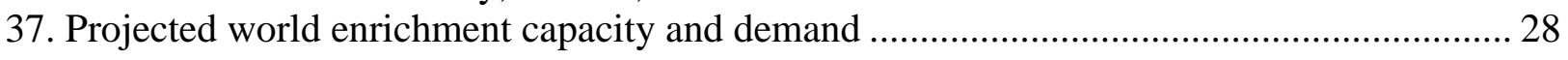





\section{LIST OF TABLES}

Table

Page

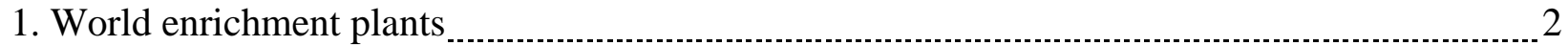

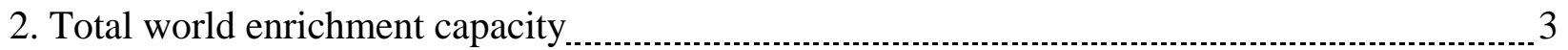





\section{ACRONYMS AND ABBREVIATIONS}

\begin{tabular}{|c|c|}
\hline AAEC & Australian Atomic Energy Commission \\
\hline ANSTO & Australian Nuclear Science and Technology Organisation \\
\hline ABACC & Brazilian-Argentine Agency for Accounting and Control of Nuclear Materials \\
\hline AEOI & Atomic Energy Organization of Iran \\
\hline AVLIS & atomic vapor laser isotope separation \\
\hline BARC & Bhabha Atomic Research Centre, India \\
\hline BNFL & British Nuclear Fuels Ltd. \\
\hline CHEM & cascade header enrichment monitor (portable) \\
\hline CEA & Commissariat à l'Énergie Atomique, France \\
\hline CEMO & continuous enrichment monitoring \\
\hline CNEA & Comisión Nacional de Energía Atómica, Argentina \\
\hline CNEN & Comissão Nacional de Energia Nuclear, Brazil \\
\hline CNNC & China National Nuclear Corporation \\
\hline DA & destructive assay \\
\hline DAE & Department of Atomic Energy, India \\
\hline DOE & Department of Energy, United States \\
\hline DPRK & Democratic People’s Republic of Korea (North Korea) \\
\hline DU & depleted uranium \\
\hline EMIS & electromagnetic isotope separation \\
\hline ES & environmental sampling \\
\hline ETC & Enrichment Technology Co., Urenco \\
\hline EURATOM & European Atomic Energy Community \\
\hline FDO & Fysisch Dynamisch Onderzoekslaboratorium \\
\hline FEP & Fuel Enrichment Plant, Natanz, Iran \\
\hline $\mathrm{F} / \mathrm{W}$ & feed and withdrawal \\
\hline GCEP & gas centrifuge enrichment plant \\
\hline GDP & gaseous diffusion plant \\
\hline GE & General Electric \\
\hline HEU & highly enriched uranium \\
\hline HSP & Hexapartite Safeguards Project \\
\hline IAEA & International Atomic Energy Agency \\
\hline INB & Indústrias Nucleares do Brasil \\
\hline IREL & Indian Rare Earths Ltd. \\
\hline ISIS & Institute for Science and International Security \\
\hline JAEA & Japan Atomic Energy Agency \\
\hline JNC & Japan Nuclear Cycle Development Institute \\
\hline JNFL & Japan Nuclear Fuel Limited \\
\hline KRL & Dr. A.Q. Khan Research Laboratory, Kahuta, Pakistan \\
\hline LES & Louisiana Energy Services \\
\hline LEU & low-enriched uranium \\
\hline LFUA & limited-frequency unannounced access \\
\hline LIS & laser isotope separation \\
\hline MLIS & molecular laser isotope separation \\
\hline MOX & mixed oxide \\
\hline NDA & nondestructive assay \\
\hline NECSA & Nuclear Energy Corporation of South Africa \\
\hline NEF & National Enrichment Facility, New Mexico \\
\hline NPT & Nuclear Non-Proliferation Treaty \\
\hline NRC & Nuclear Regulatory Commission, United States \\
\hline
\end{tabular}




$\begin{array}{ll}\text { NWS } & \text { nuclear weapons state } \\ \text { ORAU } & \text { Oak Ridge Associated Universities } \\ \text { ORNL } & \text { Oak Ridge National Laboratory } \\ \text { PAEC } & \text { Pakistan Atomic Energy Commission } \\ \text { PFEP } & \text { Pilot Fuel Enrichment Plant, Natanz, Iran } \\ \text { PNC } & \text { Power Reactor and Nuclear Fuel Development Corporation of Japan } \\ \text { PNPFC } & \text { Pakistan Nuclear Power Fuel Complex } \\ \text { ROSATOM } & \text { Russian Federal Atomic Energy Agency } \\ \text { SILEX } & \text { separation of isotopes by laser excitation } \\ \text { SWU } & \text { separative work unit } \\ \text { UF } 6 & \text { uranium hexafluoride } \\ \text { UI } & \text { unannounced inspection } \\ \text { U.K. } & \text { United Kingdom } \\ \text { U.S. } & \text { United States } \\ \text { USEC } & \text { United States Enrichment Corporation }\end{array}$

\section{ACKNOWLEDGEMENTS}

The author would like to thank the following people for reviewing and commenting on this report: from ORNL: Diane Fischer, Wayne Langenberg, Danny Powell, and Len Phillips; from DOE: Michael Whitaker and Dunbar Lockwood; from PNL: Michael Curtis and Casey Durst; from LANL: Brian Boyer. The author would also like to thank, from ORNL, Jeanne Dole for doing the technical editing and Vanessa Brown for assisting in getting this report cleared and published. 


\begin{abstract}
It is generally agreed that the most difficult step in building a nuclear weapon is acquiring weapons grade fissile material, either plutonium or highly enriched uranium (HEU). Plutonium is produced in a nuclear reactor, while HEU is produced using a uranium enrichment process. Enrichment is also an important step in the civil nuclear fuel cycle, in producing low enriched uranium (LEU) for use in fuel for nuclear reactors. However, the same equipment used to produce LEU for nuclear fuel can also be used to produce HEU for weapons. Safeguards at an enrichment plant are the array of assurances and verification techniques that ensure uranium is only enriched to LEU, no undeclared LEU is produced, and no uranium is enriched to HEU or secretly diverted.

There are several techniques for enriching uranium. The two most prevalent are gaseous diffusion, which uses older technology and requires a lot of energy, and gas centrifuge separation, which uses more advanced technology and is more energy efficient. Gaseous diffusion plants (GDPs) provide about 40\% of current world enrichment capacity, but are being phased out as newer gas centrifuge enrichment plants (GCEPs) are constructed. Estimates of current and future enrichment capacity are always approximate, due to the constant upgrades, expansions, and shutdowns occurring at enrichment plants, largely determined by economic interests. Currently, the world enrichment capacity is approximately 53 million kg-separative work units (SWU) per year, with 22 million in gaseous diffusion and 31 million in gas centrifuge plants. Another 23 million SWU/year of capacity are under construction or planned for the near future, almost entirely using gas centrifuge separation. Other less-efficient techniques have also been used in the past, including electromagnetic and aerodynamic separations, but these are considered obsolete, at least from a commercial perspective. Laser isotope separation shows promise as a possible enrichment technique of the future, but has yet to be demonstrated commercially.
\end{abstract}

In the early 1980s, six countries developing gas centrifuge technology (United States, United Kingdom, Germany, the Netherlands, Japan, and Australia) along with the International Atomic Energy Agency (IAEA) and the European Atomic Energy Community (EURATOM) began developing effective safeguards techniques for GCEPs. This effort was known as the Hexapartite Safeguards Project (HSP). The HSP had the goal of maximizing safeguards effectiveness while minimizing the cost to the operator and inspectorate, and adopted several recommendations, such as the acceptance of limited-frequency unannounced access (LFUA) inspections in cascade halls, and the use of nondestructive assay (NDA) measurements and tamper-indicating seals. While only the HSP participants initially committed to implementing all the measures of the approach, it has been used as a model for the safeguards applied to GCEPs in additional states.

This report provides a snapshot overview of world enrichment capacity in 2007, including profiles of the uranium enrichment programs of individual states. It is based on open-source information, which is dependent on unclassified sources and may therefore not reflect the most recent developments. In addition, it briefly describes some of the safeguards techniques being used at various enrichment plants, including implementation of HSP recommendations. 



\section{INTRODUCTION}

It is generally agreed that the most difficult step in building a nuclear weapon is acquiring weapons grade fissile material, either plutonium or highly enriched uranium (HEU). Plutonium is produced in a nuclear reactor, while HEU is produced using a uranium enrichment process. Enrichment is also an important step in the civil nuclear fuel cycle, in producing low-enriched uranium (LEU) for use in fuel for nuclear reactors. However, the same equipment used to produce LEU for nuclear fuel can also be used to produce HEU for weapons. Safeguards at an enrichment plant are the array of assurances and verification techniques that ensure uranium is enriched only to LEU, and none is enriched to HEU or secretly diverted. This report provides a snapshot overview of world enrichment capacity in 2007, including profiles of the uranium enrichment programs of individual states, and describes some of the safeguards techniques being used at various enrichment plants. It is based on open-source information, which is dependent on unclassified sources and may therefore not reflect the most recent developments.

\subsection{ENRICHMENT OVERVIEW}

Enrichment is the process of concentrating the fissile isotope of natural uranium, ${ }^{235} \mathrm{U}(0.711 \%$ by weight in natural uranium). Higher concentrations of ${ }^{235} \mathrm{U}$ make nuclear fission chain reactions easier to maintain. LEU (less than $20 \%{ }^{235} \mathrm{U}$ ) allows some nuclear reactor designs to produce sustained power for electricity production, while HEU (greater than $20 \%{ }^{235} \mathrm{U}$ ) allows the possibility that a chain reaction will exponentially increase, resulting in a nuclear explosion.

There are several techniques for enriching uranium. The two most prevalent are gaseous diffusion and gas centrifuge separation. Gaseous diffusion relies on the preferential permeability of ${ }^{235} \mathrm{U}$ through a porous membrane. It uses older technology and the separation factor (increase in enrichment) of a single stage is very small. More than a thousand stages must be linked in cascades (the Georges Besse plant in France uses approximately 1400 stages to produce $\mathrm{LEU}^{1}$ ), requiring a lot of energy, a large amount of in-process uranium, and a long time to reach equilibrium. Gas centrifuge separation relies on the mass difference in the uranium isotopes to concentrate heavier isotopes at the edge of a rapidly spinning cylinder. It requires somewhat more advanced technology and materials, and the separation factor per centrifuge is greater, so fewer stages are required to make a cascade, making it more energy efficient. In addition, gas centrifuge enrichment plant (GCEP) capacity can be increased simply by adding more centrifuge cascades in parallel, allowing expandability if needs change whereas gaseous diffusion plants (GDPs) are not as flexible. Other less-efficient techniques have been used in the past, including electromagnetic and aerodynamic separations, but these are considered obsolete, at least from a commercial perspective. Laser isotope separation (LIS), using laser light to selectively excite and ionize molecules (MLIS - Molecular Laser Isotope Separation) or individual atoms (AVLIS - Atomic Vapor Laser Isotope Separation), shows promise as a cost effective enrichment technique of the future, but has not yet been demonstrated commercially.

\subsection{WORLD ENRICHMENT CAPACITY}

Gaseous diffusion was initially the dominant process for providing enrichment services, and GDPs continue to provide about $40 \%$ of current world enrichment capacity. However, these older plants are being phased out as newer GCEPs are constructed. Estimates of current and future enrichment capacity are always approximate, due to the constant upgrades, expansions, and shutdowns occurring at enrichment plants, largely determined by economic interests. In addition, most plants are not continuously operated at their maximum capacities. In general, capacity does not equate directly with actual production. Table 1 gives a summary of current and planned capacity at world enrichment plants. All of the values are referenced in this report, in the text of the appropriate section for each state. 
Table 1. World enrichment plants

\begin{tabular}{|c|c|c|c|c|c|}
\hline State & Plant Name/Location & Owner/Operator & Type & Status & $\begin{array}{r}\text { Capacity } \\
(k g S W U / \text { year) }\end{array}$ \\
\hline Argentina & Pilcaniyeu & CNEA & Gaseous Diffusion & Standby & 20,000 \\
\hline Australia & Lucas Heights & AAEC & Centrifuge & Shutdown/Dismantled & Laboratory \\
\hline \multirow[t]{2}{*}{ Brazil } & Aramar & Brazilian Navy, CNEN & Centrifuge & Operating..... & 9,000 \\
\hline & Resende & INB & Centrifuge & $\begin{array}{l}\text { Operating/Under } \\
\text { Construction }\end{array}$ & 120,000 \\
\hline \multirow[t]{5}{*}{ China } & Heping & CNNC & Gaseous Diffusion & Operating & 200,000 \\
\hline & Lanzhou & CNNC & Gaseous Diffusion & Shutdown & 900,000 \\
\hline & Lanzhou & CNNC & Centrifuge & Operating & 500,000 \\
\hline & & & & Planned & 500,000 \\
\hline & Shaanxi - Hanzhong & CNNC & Centrifuge & Operating & 500,000 \\
\hline \multirow[t]{3}{*}{ France } & Pierrelatte GDP & CEA & Gaseous Diffusion & Shutdown & 500,000 \\
\hline & Georges Besse I - Tricastin & Eurodif & Gaseous Diffusion & Operating & $10,800,000$ \\
\hline & Georges Besse II - Tricastin & Areva & Centrifuge & Planned & $7,500,000$ \\
\hline \multirow[t]{2}{*}{ Germany } & Gronau & Urenco & Centrifuge & Operating & $1,800,000$ \\
\hline & & & & Planned & $2,700,000$ \\
\hline \multirow[t]{2}{*}{ India } & BARC, Trombay & DAE & Centrifuge & Operating & Pilot \\
\hline & $\begin{array}{l}\text { Rattehalli Rare Materials Plant, } \\
\text { Mysore }\end{array}$ & IREL/DAE & Centrifuge & Operating & $4-10,000$ \\
\hline \multirow[t]{2}{*}{ Iran } & Natanz PFEP & AEOI & Centrifuge & Operating...... & Pilot \\
\hline & Natanz FEP & AEOI & Centrifuge & $\begin{array}{l}\text { Operating/Under } \\
\text { Construction }\end{array}$ & 250,000 \\
\hline \multirow[t]{3}{*}{ Japan } & Ningyo-Toge Pilot \& Demo & JAEA & Centrifuge & Shutdown & 250,000 \\
\hline & Rokkasho & JNFL & Centrifuge & Operating & 300,000 \\
\hline & & & & Planned & $1,200,000$ \\
\hline \multirow[t]{2}{*}{ Netherlands } & Almelo & Urenco & Centrifuge & Operating & $3,500,000$ \\
\hline & & & & Planned & $1,000,000$ \\
\hline \multirow[t]{2}{*}{ Pakistan } & KRL Kahuta & PAEC & Centrifuge & Operating & $15-20,000$ \\
\hline & Unconfirmed plant, Kundian & PAEC & Centrifuge & Planned & Unknown \\
\hline \multirow[t]{4}{*}{ Russia } & $\begin{array}{l}\text { Urals ElectroChemical Combine - } \\
\text { Novouralsk }\end{array}$ & Rosatom & Centrifuge & Operating & $9,800,000$ \\
\hline & $\begin{array}{l}\text { Siberian Chemical Combine - } \\
\text { Seversk }\end{array}$ & Rosatom & Centrifuge & Operating & $2,800,000$ \\
\hline & $\begin{array}{l}\text { Zelenogorsk ElectroChemical } \\
\text { Plant }\end{array}$ & Rosatom & Centrifuge & Operating & $5,800,000$ \\
\hline & $\begin{array}{l}\text { Angarsk ElectroChemical } \\
\text { Combine }\end{array}$ & Rosatom & Centrifuge & Operating & $1,600,000$ \\
\hline \multirow[t]{2}{*}{ South Africa } & Z-Plant - Pelindaba & NECSA & Aerodynamic & Shutdown/Dismantled & 300,000 \\
\hline & Y-Plant - Valendaba & NECSA & Aerodynamic & Shutdown/Dismantled & 10,000 \\
\hline \multirow[t]{2}{*}{ United Kingdom } & Capenhurst & BNFL & Gaseous Diffusion & Shutdown & 350,000 \\
\hline & & Urenco & Centrifuge & Operating & $3,700,000$ \\
\hline \multirow[t]{9}{*}{ United States } & Oak Ridge GDP & US DOE & Gaseous Diffusion & Shutdown & $8,500,000$ \\
\hline & Paducah & USEC & Gaseous Diffusion & Operating & $11,300,000$ \\
\hline & Portsmouth & USEC & Gaseous Diffusion & Standby & $7,400,000$ \\
\hline & National Enrichment Facility & Urenco & Centrifuge & Under Construction & $3,000,000$ \\
\hline & Lead Cascade, Piketon & USEC & Centrifuge & Under Construction & Pilot \\
\hline & $\begin{array}{l}\text { American Centrifuge Plant, } \\
\text { Piketon }\end{array}$ & USEC & Centrifuge & Planned & $3,800,000$ \\
\hline & Unnamed Areva project & Areva & Centrifuge & Pre-licensing & $3,000,000$ \\
\hline & SILEX Test Loop, Wilmington & GE-Hitachi & SILEX & Under Construction & Pilot \\
\hline & SILEX Plant & GE-Hitachi & SILEX & Pre-licensing & $3.5-6,000,000$ \\
\hline
\end{tabular}


The capacity for plants listed as "shutdown" or "dismantled" is the maximum capacity the plant was designed for when it was operating. For plants listed as "operating/under construction," the capacity is the total design capacity; oftentimes cascades are put into operation as they are completed.

Currently, the world enrichment capacity is approximately 53 million kg separative work units (kg SWU, often referred to just as SWU in this report) per year, with 22 million in gaseous diffusion and 31 million in gas centrifuge plants (Table 2). Plants to produce another 24 million SWU/year are under construction or planned for the near future, almost entirely using gas centrifuge separation. This report only discusses enrichment facilities that use isotope separation processes to produce uranium enriched in ${ }^{235} \mathrm{U}$. A large proportion of world demand for LEU fuel is currently being met by downblending excess weapons-grade $\mathrm{HEU},{ }^{2}$ and this capacity is often reported as "SWU-equivalent," meaning the enrichment capacity that would be required to produce an equivalent amount of LEU. Mixed oxide (MOX) fuel, produced by mixing reprocessed plutonium with uranium, is also sometimes measured in SWU equivalents, and adds to the total world SWU supply.

Table 2. Total world enrichment capacity

\begin{tabular}{llc}
\hline & Operating & Planned/under construction \\
\hline Total & 53 million kg SWU/year & 24 million kg SWU/year \\
\hline Centrifuge & 31 million kg SWU/year & 24 million kg SWU/year \\
\hline Gaseous diffusion & 22 million kg SWU/year & $\begin{array}{c}20,000 \mathrm{~kg} \text { SWU/year } \\
\text { (planned restart of Pilcaniyeu) }\end{array}$ \\
\hline
\end{tabular}

\subsection{THE HEXAPARTITE SAFEGUARDS PROJECT}

In the early 1980s, six countries with gas centrifuge technology (United States, United Kingdom, Germany, the Netherlands, Japan, and Australia) along with the International Atomic Energy Agency (IAEA) and the European Atomic Energy Community (EURATOM) began investigating effective safeguards techniques for GCEPs. This effort was known as the Hexapartite Safeguards Project (HSP). The HSP had four specific objectives for maximizing effectiveness and efficiency ${ }^{3}$ :

1. Maximize safeguards (verification) effectiveness;

2. Minimize the risk of acquiring sensitive information and technology by the inspectorate;

3. Minimize the intrusiveness and cost to facility operators; and

4. Minimize inspectorate resource requirements to carry out the verification.

The HSP reached a consensus that HEU production was a greater proliferation risk than LEU diversion, and focused verification techniques on the detection of HEU. The project adopted several recommendations, including the acceptance of random limited-frequency unannounced access (LFUA) to cascade halls, the necessity of inspector access to cascade halls within 2 hours of the request (2 hours was considered long enough for the operator to protect proprietary information but not long enough to remove all evidence of illicit activity), and the use of nondestructive assay (NDA) measurements and tamperindicating seals. While only the HSP participants initially committed to implementing all the measures of the approach, it has been used as a model for the safeguards applied to GCEPs in additional states. The IAEA investigates new measures and incorporates new technologies as the techniques and implementation of safeguards continue to evolve. This includes expanding its authority by implementing strengthened safeguards and encouraging states to adopt an Additional Protocol, and integrating advanced technologies to assist in better meeting the HSP goal of detecting diversion or misuse of declared material at declared facilities. Additional measures, such as environmental sampling (ES) and wide-area monitoring, provide some capability to detect undeclared feeds, materials and activities, which were all beyond the scope of the original HSP. 


\section{P-5 STATES}

The Nuclear Non-Proliferation Treaty (NPT) recognizes five nuclear weapons states (NWS), those that "manufactured and exploded a nuclear weapon or other nuclear explosive device prior to January 1 , 1967" " United States, United Kingdom, Russia, France, and China. These states are also the five permanent members of the UN Security Council, designated the "P-5." The NWS are not required under the NPT to have their nuclear facilities and material safeguarded by the IAEA. However, they can designate some facilities and material to be put under safeguards as part of a "voluntary offer," as a gesture of goodwill or to ease multinational collaboration. In addition, a supplier state can require that nuclear material from that state be put under safeguards as a condition of exporting to a NWS (e.g., Australia's conditions on selling uranium to China) ${ }^{5}$.

\subsection{UNITED STATES}

The United States implemented uranium enrichment on an industrial scale as part of the Manhattan Project to build a nuclear weapon during World War II. The first techniques used were thermal diffusion, which was quickly abandoned, and electromagnetic isotope separation (EMIS), where ionized atoms are separated by traveling through a strong magnetic field. Large EMIS machines called calutrons were built at the Oak Ridge Y-12 Plant and supplied the HEU for the United States' first weapon (Fig.1). By the end of the war in 1945, a GDP process building designated K-25 (Fig. 2) had been constructed at Oak Ridge with a capacity of about 100,000 SWU/year. Over the next 10 years additional process buildings were built at the site, which continued to be referred to as "K-25" although strictly this only refers to the first process building. The whole facility was the Oak Ridge GDP, which reached a maximum capacity of $8,500,000$ SWU/year in the early 1980s through numerous equipment improvements and power supply increases. ${ }^{6}$

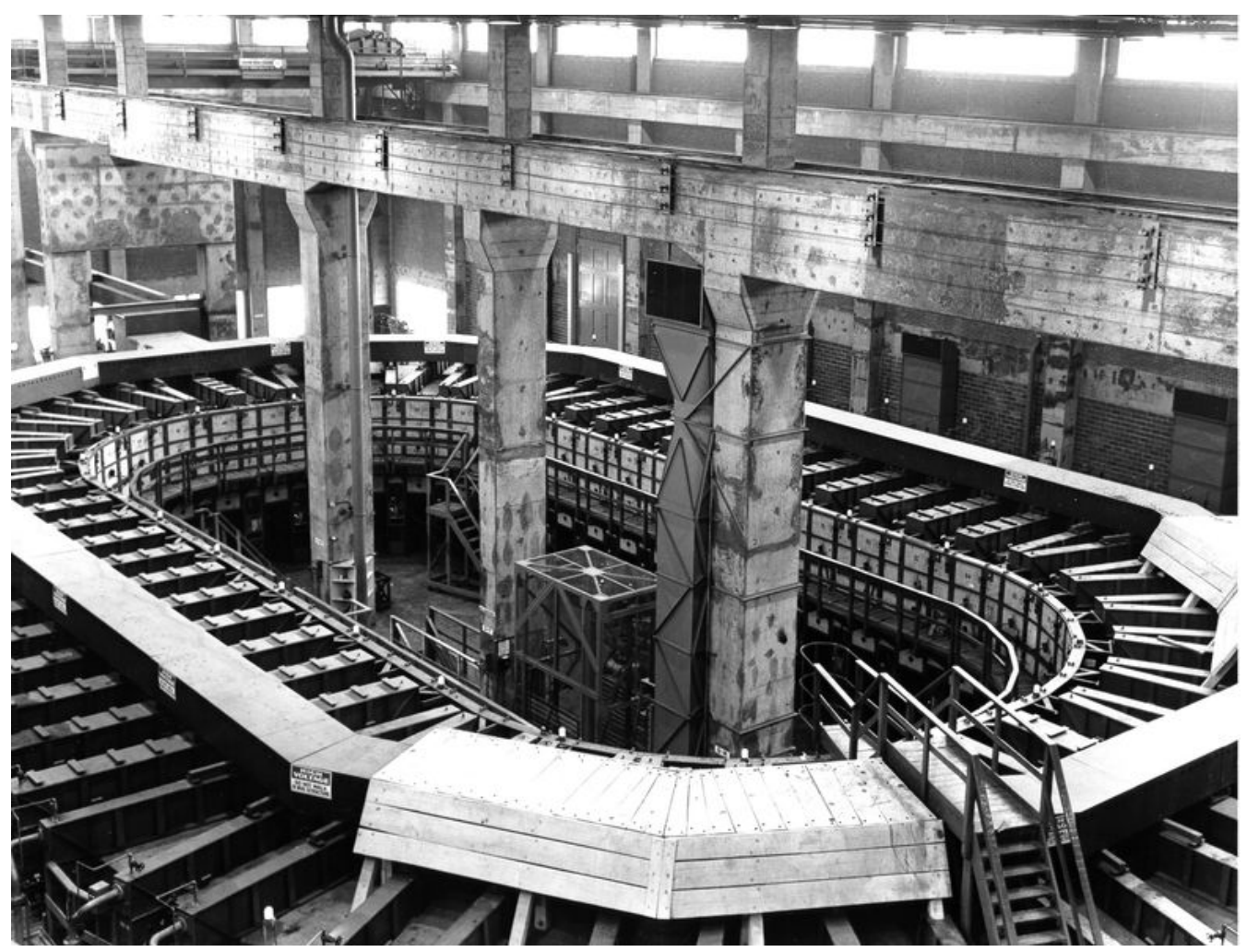

Fig. 1. Alpha Calutron track, Y-12 Plant, United States. 
In the 1950s, the United States constructed two more large GDPs to increase production capacity: one at Paducah, Kentucky (Fig. 3), that first produced enriched uranium in 1952 and was completed in 1954 (maximum capacity in the 1980s of 11,300,000 SWU/year), the other at Piketon, Ohio (Fig. 4), near Portsmouth that went online in 1956 (maximum capacity in the 1980s of 7,400,000 SWU/year). In the 1960s, the United States ceased enriching uranium for weapons and began producing LEU for commercial power plants, in addition to continuing to produce HEU for fuel for research reactors and nuclear submarines. The Oak Ridge GDP continued producing LEU for commercial power plants until it was shut down in 1985. The Portsmouth GDP produced HEU for research reactors and submarines until the "top end" was shut down in the early 1990s, but continued to produce LEU until the rest of the plant was put on standby in 2001. All current uranium enrichment in the United States takes place at the Paducah GDP, ${ }^{7}$ which currently operates at about $2 / 3$ capacity due to power supply limitations.

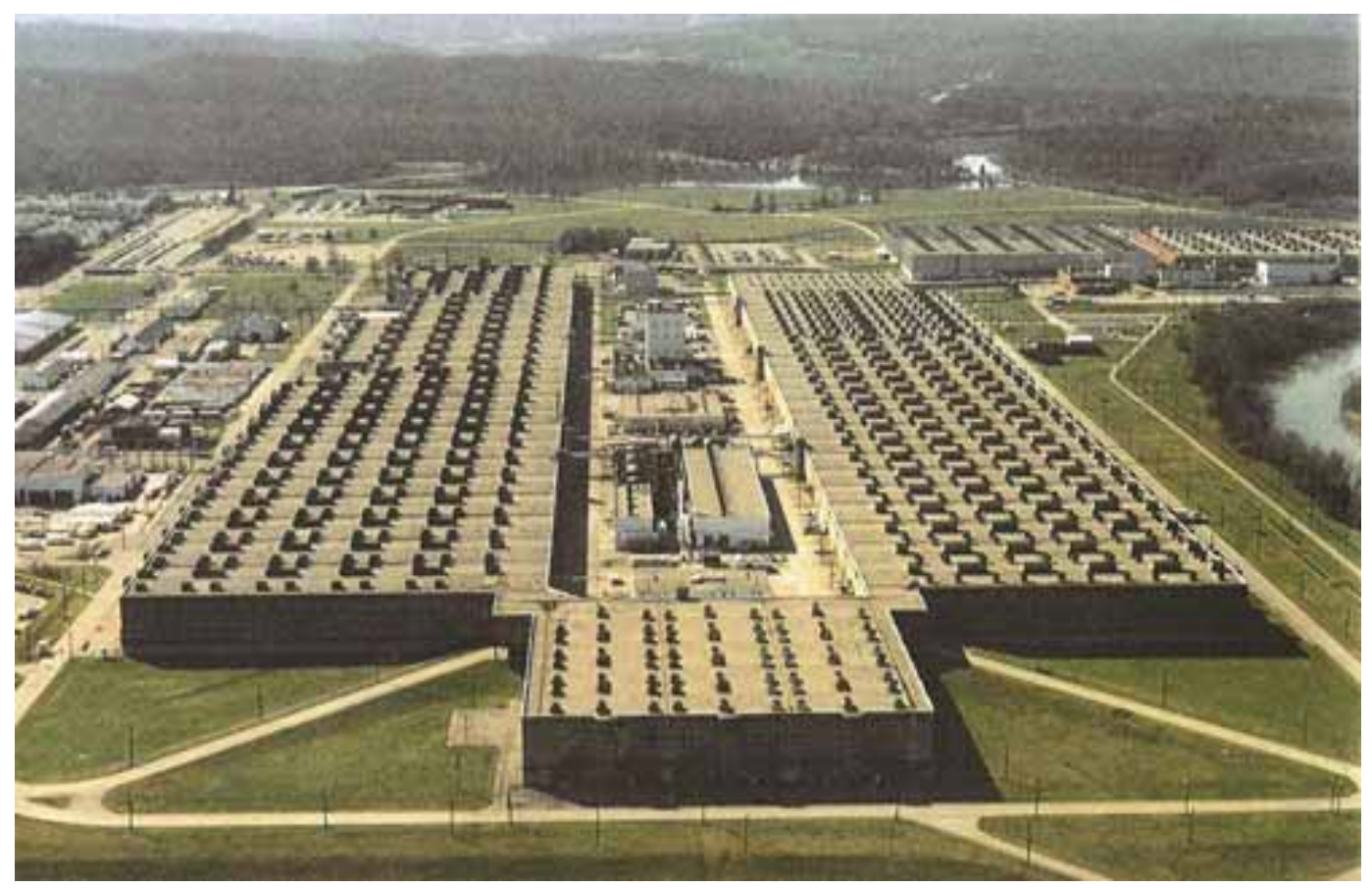

Fig. 2. K-25 building at the Oak Ridge GDP, United States.

In the 1960s the U.S. Atomic Energy Commission, predecessor to the Department of Energy (DOE), began investigating centrifuge enrichment, and in the 1970s and 80s developed an advanced centrifuge design and began constructing a GCEP near its GDP in Piketon, Ohio. More than 1300 centrifuges had been installed at the facility by 1985, when the project was shut down. Finishing and operating the plant seemed uneconomical, because SWU demand had fallen short of earlier projections and was being met by the GDPs. In addition, the United States had decided to refocus research and development efforts on AVLIS technology, ${ }^{8}$ work that was suspended in $1999 .{ }^{9}$ These centrifuges were stored until 2006 (Fig. 6), when they were dismantled and buried at the Nevada Test Site. ${ }^{10}$

The United States Enrichment Corporation (USEC), the current operator of the Portsmouth and Paducah GDPs, has been constructing since May 2007 a GCEP called the American Centrifuge Plant at its Portsmouth site, in the building that originally housed the DOE centrifuge project in the 1980s. The USEC centrifuge design is also based largely on the DOE design from that project. USEC has constructed a "Lead Cascade" demonstration facility and is testing the individual centrifuges with uranium gas. USEC expects to operate the full cascade by October 2007 and begin commercial operations at the facility by the end of the decade. ${ }^{11}$ 


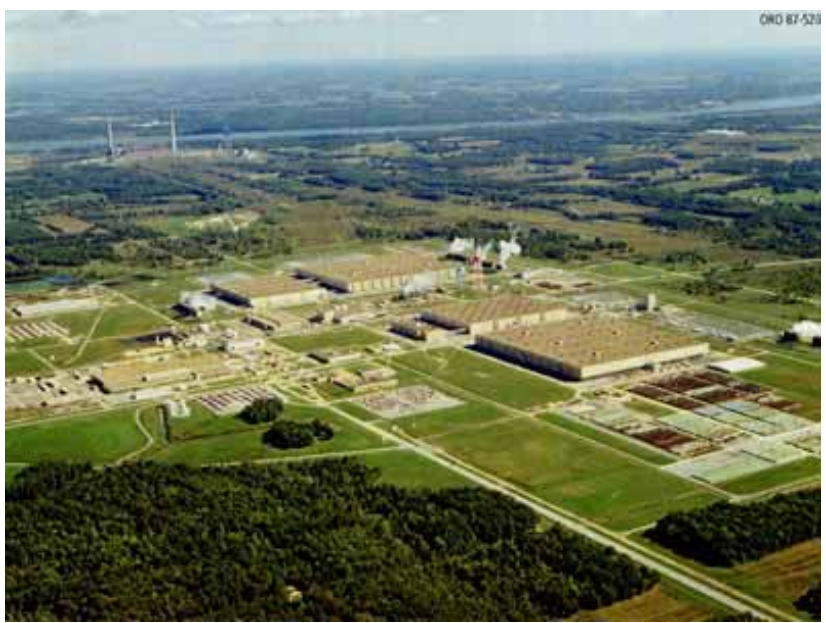

Fig. 3. Paducah GDP, United States.

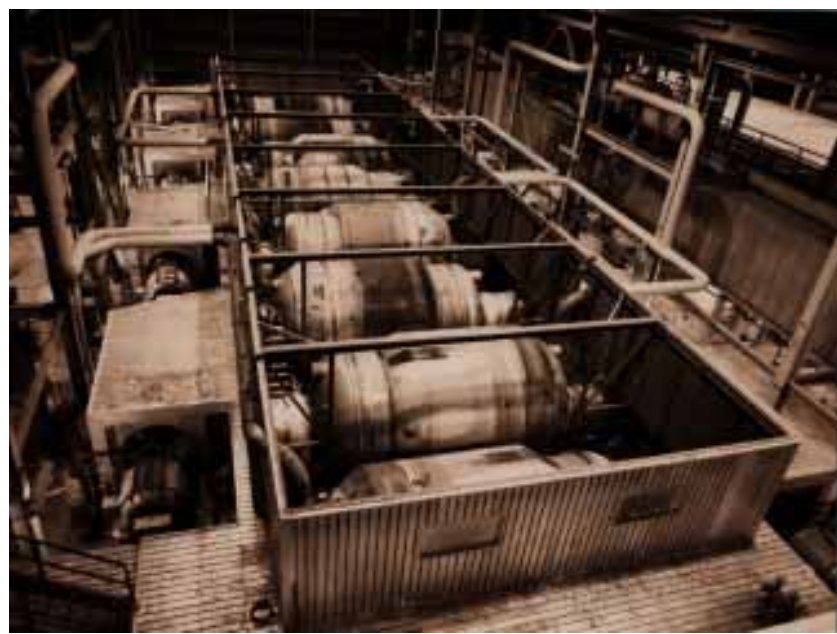

Fig. 5. Gaseous diffusion cell, United States.

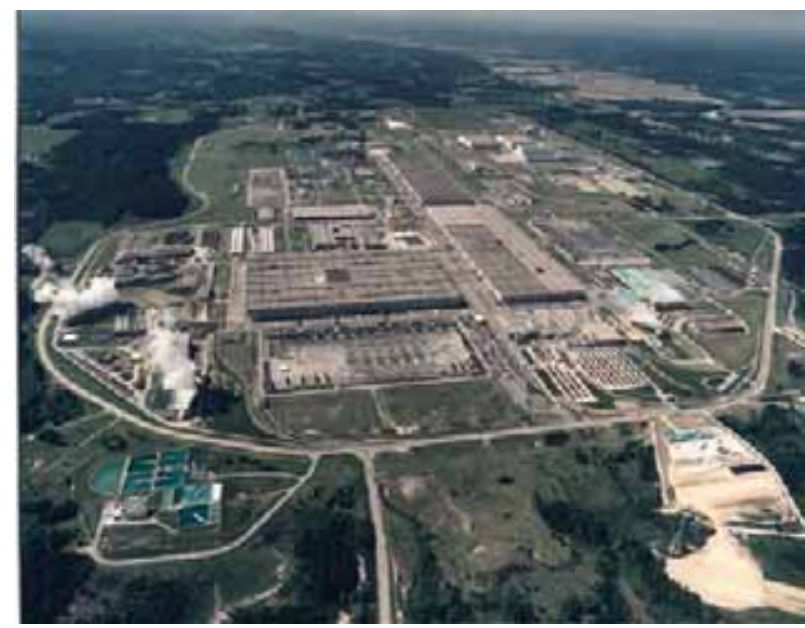

Fig. 4. Portsmouth GDP, United States.

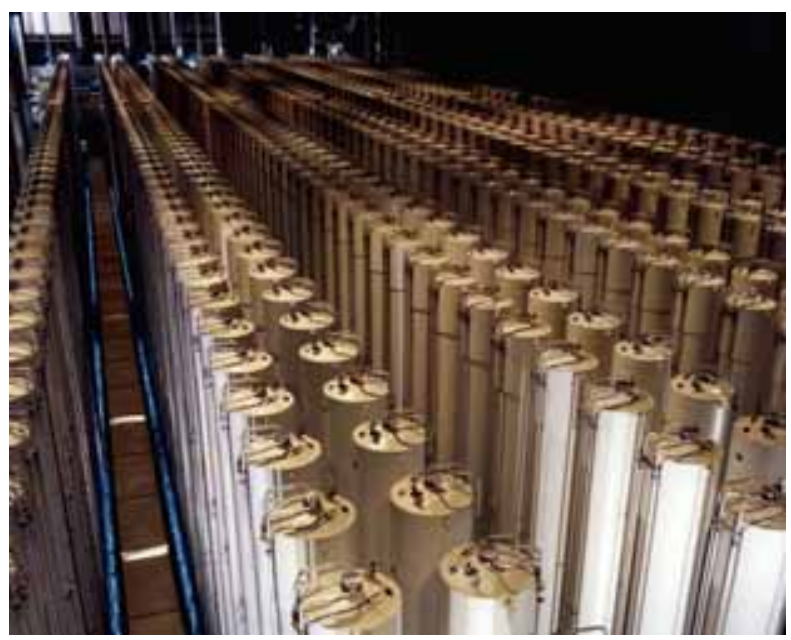

Fig. 6. U.S. DOE centrifuges, United States.

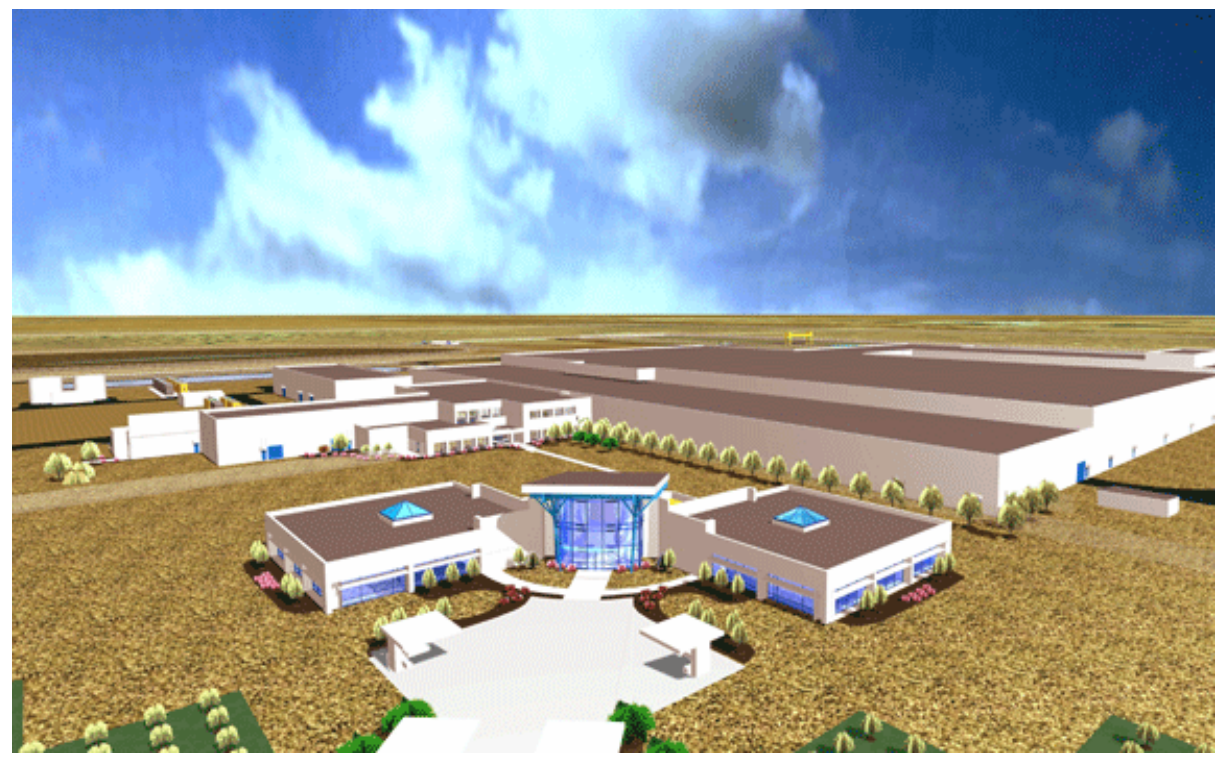

Fig. 7. National Enrichment Facility visual model, United States.

Source: nefnm.com 
Louisiana Energy Services (LES), a Urenco subsidiary ${ }^{12}$, is licensed by the U.S. Nuclear Regulatory Commission (NRC) to build a 3 million SWU/year GCEP in the United States and began construction on the National Enrichment Facility (NEF) (Fig. 7) near Eunice, New Mexico, in 2006. ${ }^{13}$ The license, issued in June 2006, authorizes LES to produce LEU up to $5 \%{ }^{235}$ U for use as nuclear fuel in commercial power plants. The plant is expected to start initial operation in 2008, with full capacity reached in $2013 .^{14}$

In May 2007, Areva held a pre-application meeting with the NRC on constructing another 3 million SWU/year gas centrifuge plant in the United States. This project is still in the initial planning phase and a site is not scheduled to be selected until the end of 2007, but Areva plans to start construction in 2010 and initial operation by $2013 .^{15}$

A laser isotope separation process called SILEX (separation of isotopes by laser excitation), a variation of MLIS, has been developed by Silex Systems Limited at the Lucas Heights Science and Technology Centre in Australia. In 1996, USEC secured the rights to evaluate and develop SILEX for commercial uranium enrichment. In May 2000, President Clinton and the U.S. Congress approved a U.S.-Australian agreement for cooperation on the development of SILEX technology. In June 2001, SILEX technology was officially classified by the U.S. and Australian governments, bringing the project formally under the security and regulatory protocols of each country. USEC relinquished its rights in 2003, and Silex signed a "Commercialization and License Agreement" with General Electric (GE) in May 2006. ${ }^{16}$ In October 2006, Silex announced that it and GE have received U.S. government authorization to proceed with an agreement granting GE exclusive rights to develop and commercialize SILEX uranium enrichment technology. The SILEX process is also being used in Australia to enrich lighter elements, such as silicon and zirconium. The uranium enrichment application of SILEX is currently in the final stage, the "Test Loop” phase, of a three-stage development program. The Test Loop is being constructed at GE's fuel fabrication facility in Wilmington, NC, to simulate a full-scale facility for performance and reliability verification (GE and Japan-based Hitachi formed a joint venture of their nuclear businesses in early 2007. GE-Hitachi Nuclear Energy encompasses the power reactor and fuel cycle operations of both companies, including the SILEX project in Wilmington. ${ }^{17}$ ) After successful completion of the Test Loop stage, planned for the end of 2008, licensing and construction will begin on the "Lead Cascade" commercial production plant, which is expected to begin operation around 2012. ${ }^{18}$ Early projections by GE-Hitachi state that the eventual commercial SILEX facility in the United States will have a capacity of between 3.5-6 million SWU/year, and several nuclear utilities have signed non-binding letters of intent to contract for enrichment services when the commercial facility becomes operational. ${ }^{19}$

\subsection{UNITED KINGDOM}

The United Kingdom constructed a GDP near Capenhurst. The plant had a maximum capacity of approximately 350,000 SWU/year and began operation in $1953 .{ }^{20}$ British Nuclear Fuels Ltd. (BNFL) took control of the plant in 1971, and it was shut down in 1982. Full decommissioning is expected to be completed in $2009 .^{21}$

BNFL began construction of a GCEP at Capenhurst in 1973. A 200,000 SWU/year demonstration plant (designated E21) began operation in 1976, was completed in 1980, and was shut down in 2000. A larger facility, E22, was started in 1982 and ultimately increased the site capacity to 1,000,000 SWU/year. In 1985, the facility A3 was constructed to provide enrichment for defense needs. The facility A3 was later converted to commercial enrichment. The E23 facility began operating in 1997 and is continuing to add capacity. The GCEP at Capenhurst is currently operated by Urenco. The entire site capacity is reported to be approximately 3,700,000 SWU/year. ${ }^{22}$

All of the HSP measures have been implemented at the Capenhurst facility (Fig. 8). Inspections are performed jointly by the IAEA and Euratom. Following Program 93+2, UK accepted ES as a Part 1 
strengthening measure. Capenhurst has also allowed continuous (on-line) enrichment monitoring (CEMO) since about 1995. The CEMO system transmits a simple go/no-go message daily to the IAEA, indicating that the system is operating properly and the measured enrichment is within the bounds of the declaration. If the CEMO transmits that something is out of the ordinary, an inspector must be sent to determine what the problem is. In the early 1990s, the British Support Program to the IAEA installed the CEMO system for the product header pipes. Prior to that, U.K. allowed the IAEA to measure enrichment (again with go/no-go determination only) with a portable germanium detector acting as a cascade header enrichment monitor (CHEM), but only at the location selected by U.K. outside the cascade hall. The CEMO systems have been installed on product header pipes at the facility and provide data directly to IAEA Headquarters in Vienna via a remote data transfer.

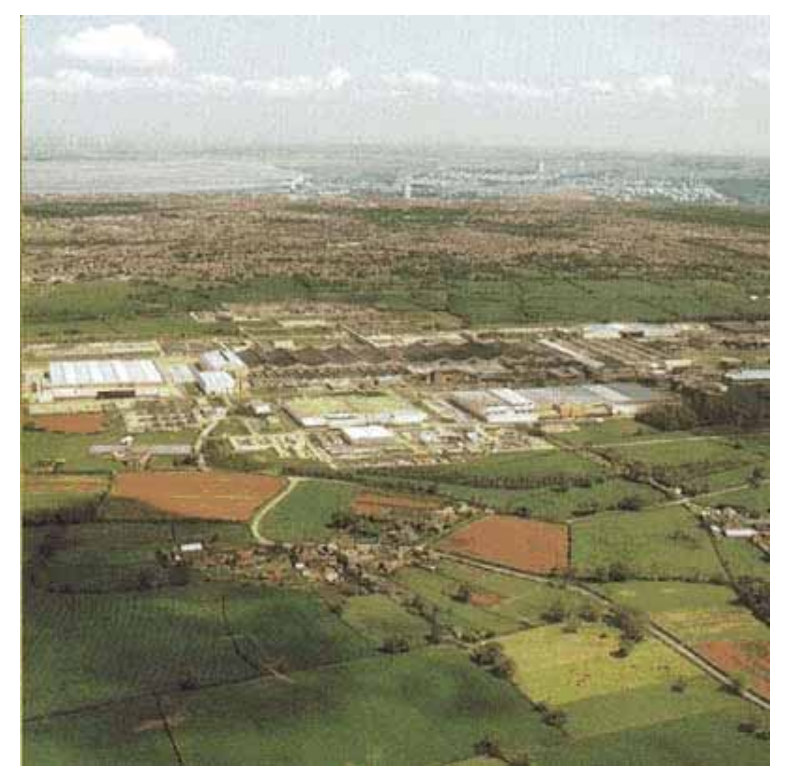

Fig. 8. Urenco Capenhurst, U.K. Source: GlobalSecurity.org

The British have stated that they developed this system in recognition that future cascade designs would be much more dynamic and flexible. Video surveillance cameras are installed in locations that are not visually accessible for LFUAs. Although the GDP at Capenhurst has been completely dismantled, the remnants of past HEU production are still detectable by the ES activities at the adjacent centrifuge facility. $^{23}$

\subsection{RUSSIA}

The Russian effort to enrich uranium started immediately after World War II. Russia (the Soviet Union, at that time) began using gaseous diffusion technology, but refocused on gas centrifuge enrichment much earlier than the United States, opening its first industrial centrifuge facility in the early 1960s. Russian innovation in the early 1950s led directly to some of the principles of centrifuge design (magnetic bearings, stationary scoops, short, subcritical rotors, etc.) widely used today by Russia, Urenco, and others. In the 1970s and 80s, Russia replaced all of its gaseous diffusion equipment with several generations of centrifuges; the pre-assembling of 20-machine "aggregates" (Fig. 14) by the manufacturers allowed centrifuges to be rapidly installed in former gaseous diffusion buildings. The Russian centrifuge program is run by state-owned Tekhsnabexport, now a subsidiary of Atomenergoprom, a company created in 2007 as an umbrella organization for the Russian civil nuclear industry. Russia is operating plants at four sites: (1) the Urals ElectroChemical Combine in Novouralsk, formerly referred to as Sverdlovsk-44, near Ekaterinburg (9,800,000 SWU/year); (2) the Siberian Chemical Combine in Seversk, formerly Tomsk-7 (2,800,000 SWU/year); (3) the ElectroChemical Plant in Zelenogorsk, formerly 
Krasnoyarsk-45 (5,800,000 SWU/year); and (4) the Angarsk ElectroChemical Combine (1,600,000 SWU/year). Russia's four plants (Figs. 9-13) account for approximately $40 \%$ of the world's operating enrichment capacity. Russia is continuing to increase its enrichment capacity by upgrading centrifuges to $7^{\text {th }}$-, $8^{\text {th }}$-, and $9^{\text {th }}$-generation designs; the capacity is expected to reach 25 million SWU/year by 2010 and will continue to increase as older centrifuges reach the end of their design life and are replaced. ${ }^{24}$

Russia currently has more enrichment capacity than is required for domestic fuel production and there is not sufficient demand for LEU for export to utilize the rest of the capacity. It has therefore, since the mid1990s, been accepting depleted uranium tails from Urenco and Areva for re-enrichment, producing natural-equivalent uranium and lower-assay tails, as well as some slightly enriched uranium to use as downblending feedstock, with its surplus enrichment capacity. ${ }^{25}$ This helps to supplement Russia's limited natural uranium supply (due largely to the loss of Kazakhstan's uranium reserves after the breakup of the Soviet Union). However, Rosatom has announced that it is phasing out re-enrichment of depleted uranium (DU) in anticipation of increased world demand of enrichment for LEU production and other economic concerns. ${ }^{26}$

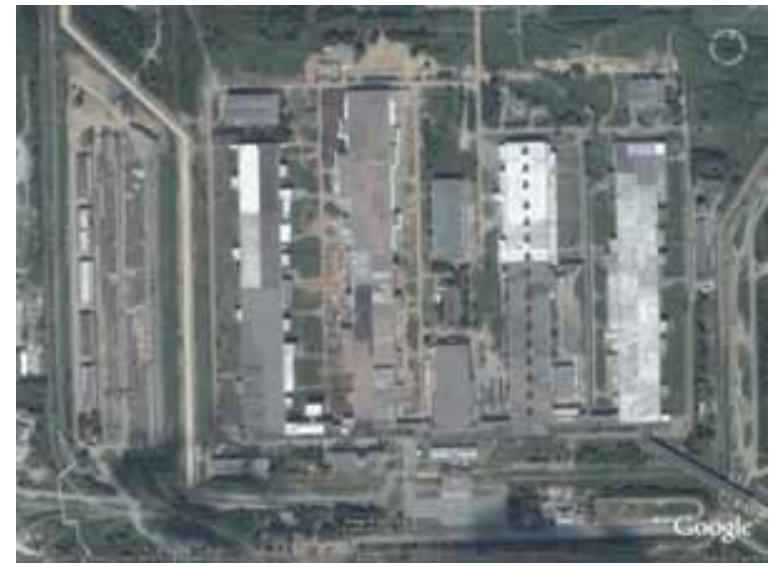

Fig. 9. Novouralsk module 3, Russia

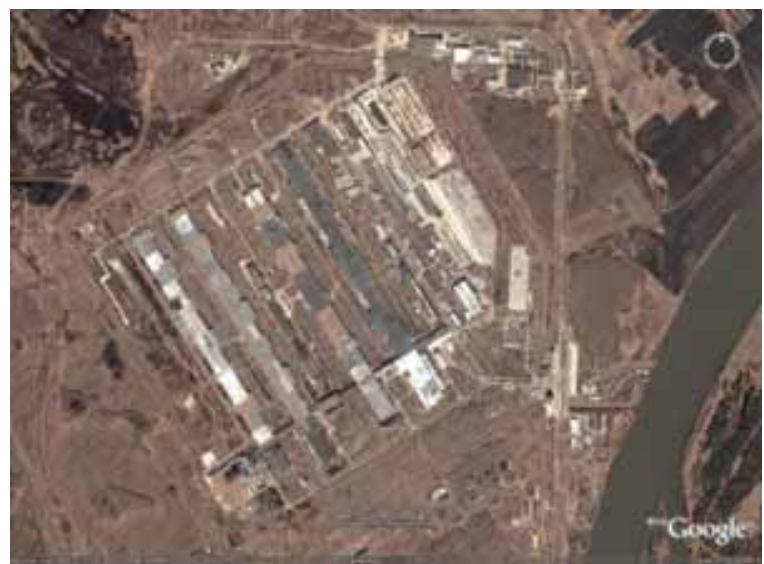

Fig. 11. Zelenogorsk, Russia

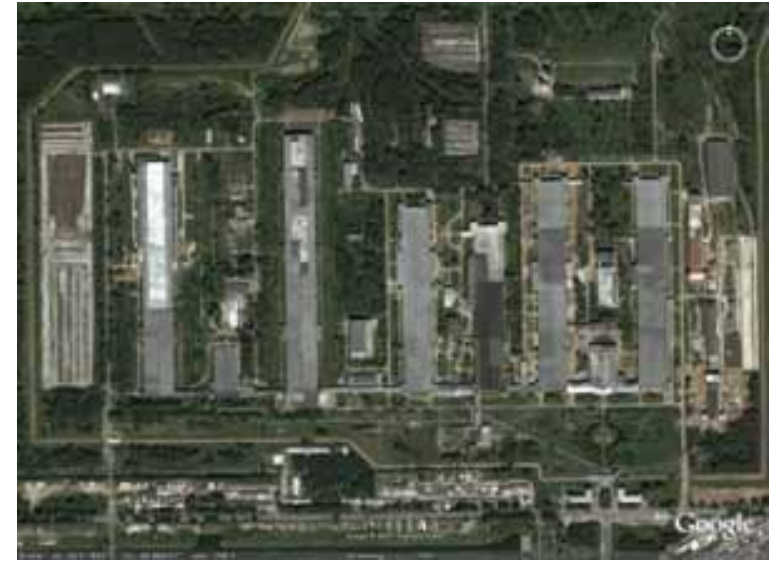

Fig. 10. Seversk, Russia

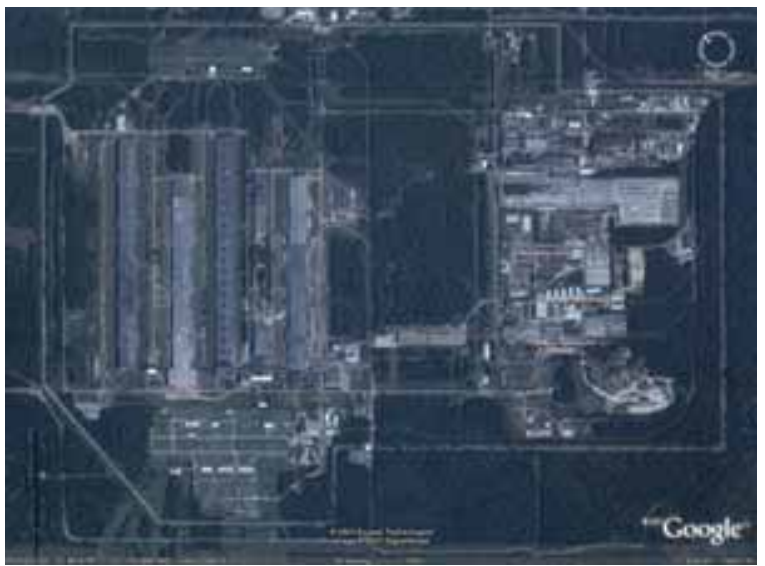

Fig. 12. Angarsk, Russia

Source for Figures 9-12: Google Earth

None of the Russian facilities have ever been subject to IAEA safeguards, but Russia has allowed the IAEA to conduct carefully designed and controlled ES field trials at Angarsk. On July 15, 2006, RIA Novosti reported: "Russia’s nuclear chief (Sergei Kiriyenko) said the first international uranium enrichment center would be established in Angarsk, in southeast Siberia's Irkutsk Region,” and that "Russian and U.S. experts had already started combining Russia’s proposal for creating a network of 
international uranium enrichment centers, and the U.S. initiative on global partnership in the nuclear sphere. ${ }^{27}$ Russia added the international fuel services center in Angarsk to its "eligible facility list” for safeguarding as part of its voluntary offer. Currently, the level of safeguards at the center has not been determined.
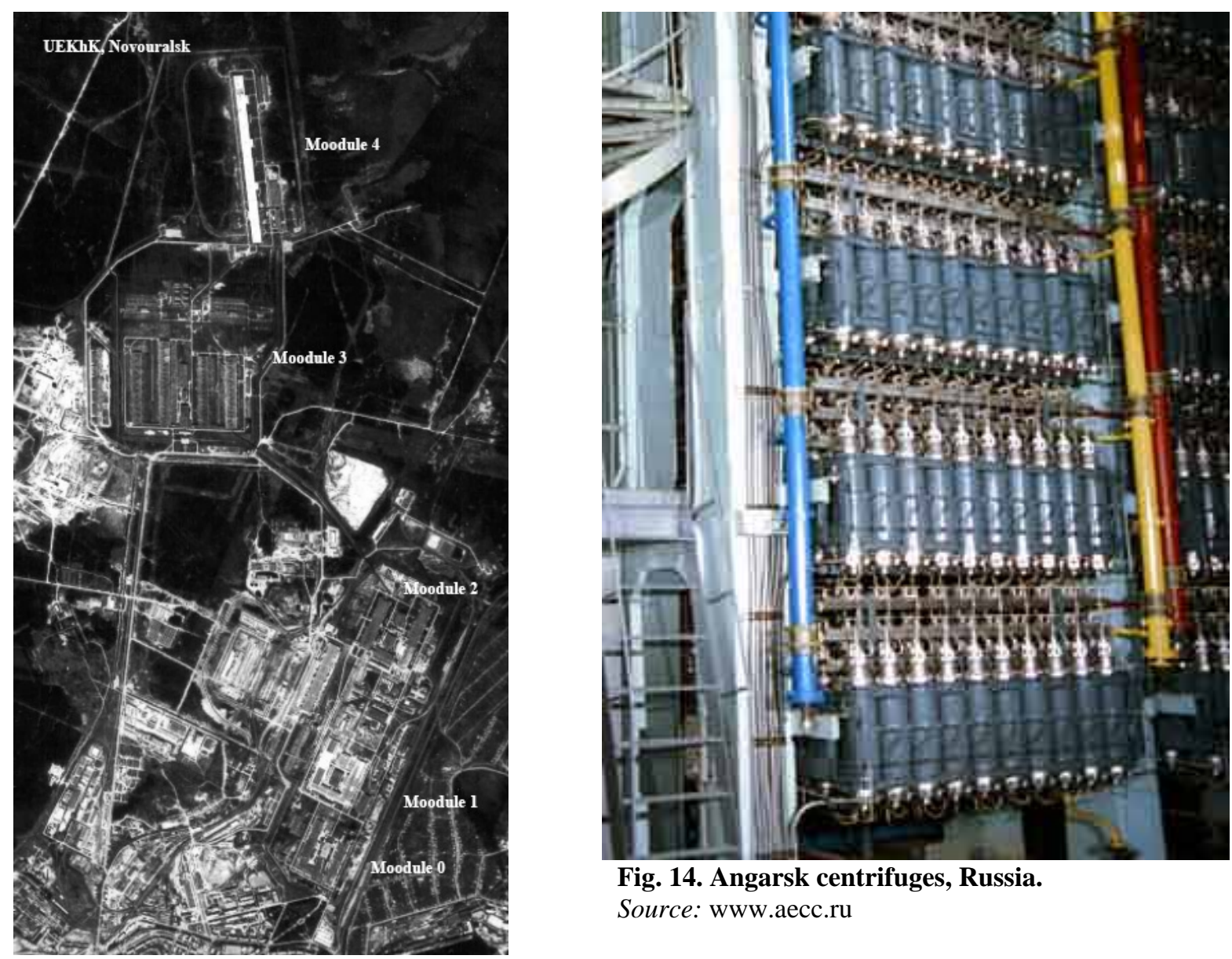

Fig. 14. Angarsk centrifuges, Russia.

Source: www.aecc.ru

Fig. 13. Novouralsk enrichment complex, Russia.

Source: Bukharin, 2004.

\subsection{FRANCE}

France constructed a GDP at Pierrelatte to produce HEU for nuclear weapons. HEU production started in 1967, and the plant's estimated capacity was around 500,000 SWU/year. ${ }^{28}$ The lower stages of the plant were shut down in the early 1980s. In February 1996, President Jacques Chirac announced that France would permanently stop producing fissile material for nuclear weapons and would immediately shut down and dismantle the remaining stages of the Pierrelatte enrichment plant. ${ }^{29}$ HEU production at Pierrelatte stopped by the middle of that year. ${ }^{30}$

The Eurodif (Georges Besse I) gaseous diffusion plant in Tricastin began operation in 1979 and was completed in 1982 (Figs. 15, 16). It consists of four process buildings, having a total capacity of $10,800,000$ SWU/year. ${ }^{31}$ This facility is subject to Euratom safeguards, but is not subject to IAEA safeguards. Gaseous diffusion requires a tremendous amount of electricity, so the Eurodif plant is run at its maximum capacity during off-peak periods when electricity is cheapest, and production is scaled back when electricity demand rises. Eurodif is powered by a direct connection to the four-reactor Tricastin nuclear power station, and uses almost their entire electricity output during peak operation. ${ }^{32}$ 


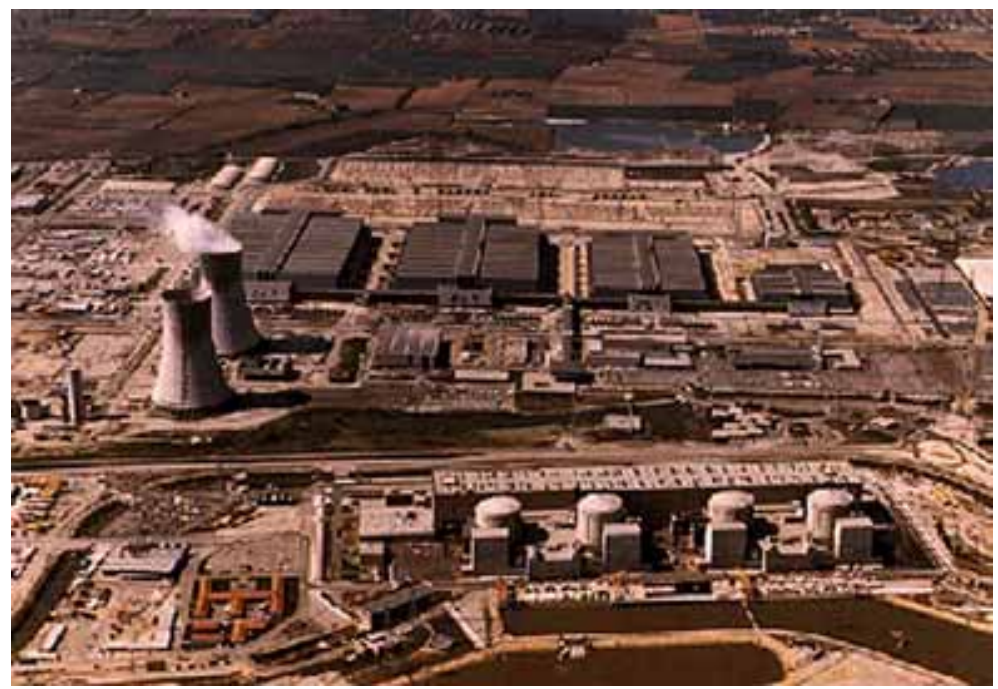

Fig. 15. Eurodif GDP, France. Source: GlobalSecurity.org

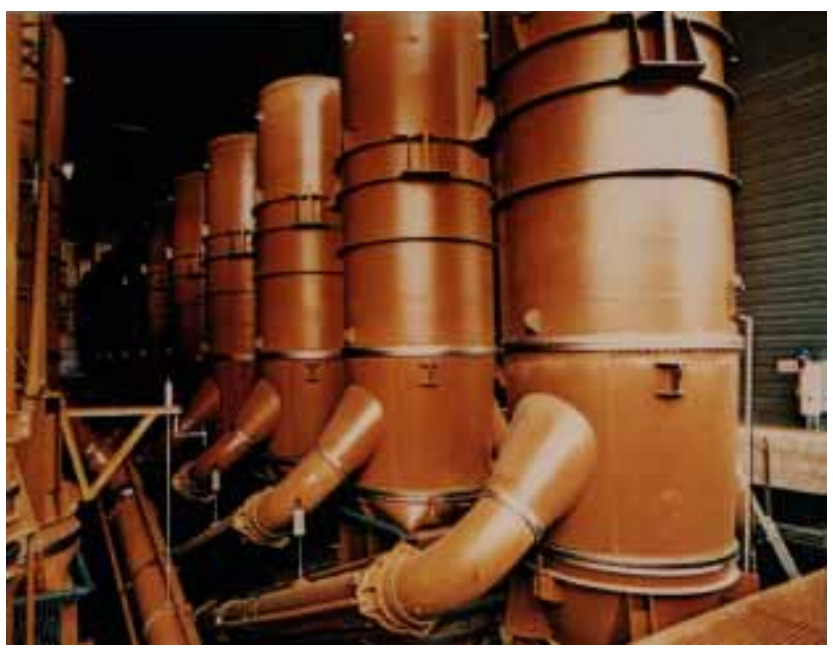

Fig. 16. Eurodif diffusion stages, France.

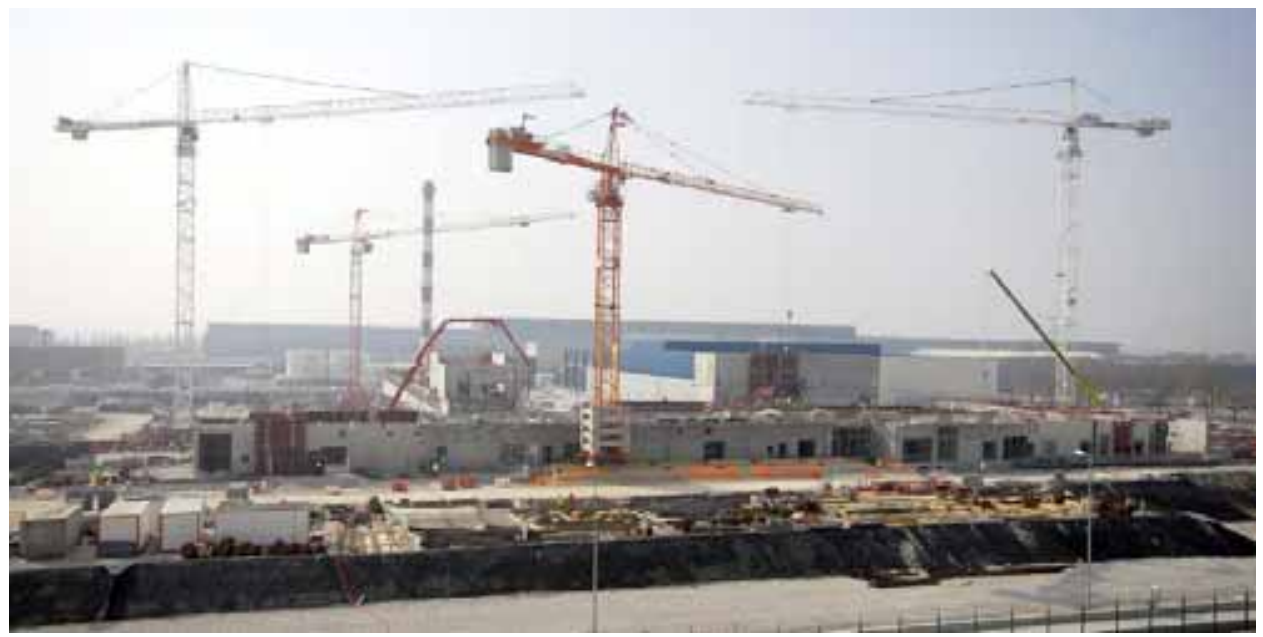

Fig. 17. Georges Besse II plant under construction, March 2007. 
In July 2006, Areva (parent company of Cogéma) and Urenco announced that they had finalized a "Joint Venture” under which Areva will acquire 50\% ownership of Urenco’s Enrichment Technology Co. (ETC). The agreement had to be approved by the European Commission, and an intergovernmental agreement had to be signed by Germany, the Netherlands, the UK, and France (the Cardiff Agreement). ETC will design and furnish Areva with the centrifuges for a centrifuge plant, Georges Besse II, being built at Tricastin. ${ }^{34}$ Construction on the plant began in September 2006 (Fig. 17). The initial cascades are scheduled to begin operating in 2009, and the plant is expected to ramp up to a full capacity of 7.5 million SWU/year by 2018. The plant's initial license was granted in April 2007 for a maximum capacity of 8.2 million SWU/year and a maximum enrichment of $6 \%{ }^{235} U{ }^{35}$ When the Georges Besse II plant comes online and the Eurodif GDP is shut down, the electricity produced by the four Tricastin reactors will be largely freed up for other uses, since centrifuge enrichment is roughly 50 times more electrically efficient than gaseous diffusion. ${ }^{36}$

\subsection{CHINA}

The Chinese gaseous diffusion plant in Lanzhou started operation in 1964 and reached a capacity of approximately 200,000 SWU/year by the late 1970s. The plant was further enlarged for commercial operation and incorporated advances in diffusion barrier technology, ${ }^{37}$ and had a reported capacity of 500,000 SWU/year when it was shut down in 1997. A second gaseous diffusion plant, the Heping plant near Chengdu, which is still operating, is reported to have a capacity of 200,000 SWU/year. Neither of these gaseous diffusion plants has been subject to IAEA safeguards.

China started researching gas centrifuge technology in the late 1950s. In 1993 Russia and China reached an agreement to build a gas centrifuge plant in China using Russian centrifuge technology. The initial plant was built at Hanzhong in Shaanxi province with a capacity of 200,000 SWU/year and was commissioned in June 1996. The capacity was increased to 500,000 SWU/year in 1998 with the addition of a second plant at the site. A third gas centrifuge plant with a capacity of 500,000 SWU/year, which was originally going to be built with the other plants in Hanzhong, has instead been built at Lanzhou to take on the workers from the shutdown Lanzhou GDP. ${ }^{38}$ Another 500,000 SWU/year centrifuge plant at Lanzhou is planned. ${ }^{39}$

According to a Tripartite Agreement between China, Russia, and the IAEA, Russian-built plants in China are available for safeguarding, but only the Hanzhong gas centrifuge plants in Shaanxi have been subject to IAEA safeguards (since China is a nuclear weapons state, safeguarding additional facilities is of low priority to the IAEA due to limited resources). ${ }^{40}$ The safeguards approach for this facility was studied as part of the Tripartite Enrichment Project, which studied safeguards approaches for plants equipped with Russian centrifuge technology. Some techniques are not feasible at this facility: Russian centrifuge systems use steel piping, making CEMOs less effective; the piping arrangement in Russian-designed plants is more flexible, meaning that installed systems could be easily bypassed; and due to China's size and the location of the Shaanxi plant, unannounced inspections would not be effective. An approach has been adopted which includes routine inspections with material accounting, modified ES, and SWUbalancing calculations. ${ }^{41}$

\section{OTHER HSP STATES}

Urenco was founded in 1971 by the national enrichment companies of the UK (BNFL), the Netherlands (Ultra-Centrifuge Nederland NV), and Germany (Uranit GmbH), following the signing of the Treaty of Almelo in March 1970 that was the basis for collaboration between these three states on development of centrifuge technology. The three companies formally merged under Urenco in 1993. Urenco today is an enrichment services company that operates GCEPs in the Netherlands, Germany, and the United Kingdom, and is constructing a GCEP in the United States. Furthermore, Urenco has an enrichment technology group that designs and develops proprietary centrifuges for its plants, and it will also be 
supplying the centrifuges for the new Areva GCEP in France. It is aggressively expanding capacity at its existing enrichment plants and aims to have total capacity in Europe of 11,000,000 SWU/year by 2010, not including the joint venture with Areva in France. ${ }^{42}$

\subsection{GERMANY}

Construction of the Gronau centrifuge plant began in April 1982 and the first cascades were started in August 1985 (Fig. 18). Initially, the facility was licensed for up to 1,000,000 SWU/year. In October 1997, the German authorities granted a license to increase the capacity to 1,800,000 SWU/year, the current capacity. In 1998, Urenco announced plans to build a new 2,200,000 SWU/year plant at the Gronau site and has formally applied for a license to increase the total capacity to 4,500,000 SWU/year. ${ }^{43}$ The plant at Gronau uses block-mounted centrifuges (Fig. 19), which have multiple rotors in a single vacuum casing.

All of the HSP measures have been implemented at the Gronau facility, but the IAEA had difficulty implementing the portable NDA header pipe measure, CHEM, to detect HEU because of the extremely low gas pressure, the large deposit-to-gas ratio, the small pipe diameter, and the limited measurement time in the cascade hall during an LFUA. ${ }^{44}$ The Germans have accepted environmental swipe sampling as part of the agreed upon Part 1 measures following Program 93+2; however, they are not implementing CEMO at Gronau.

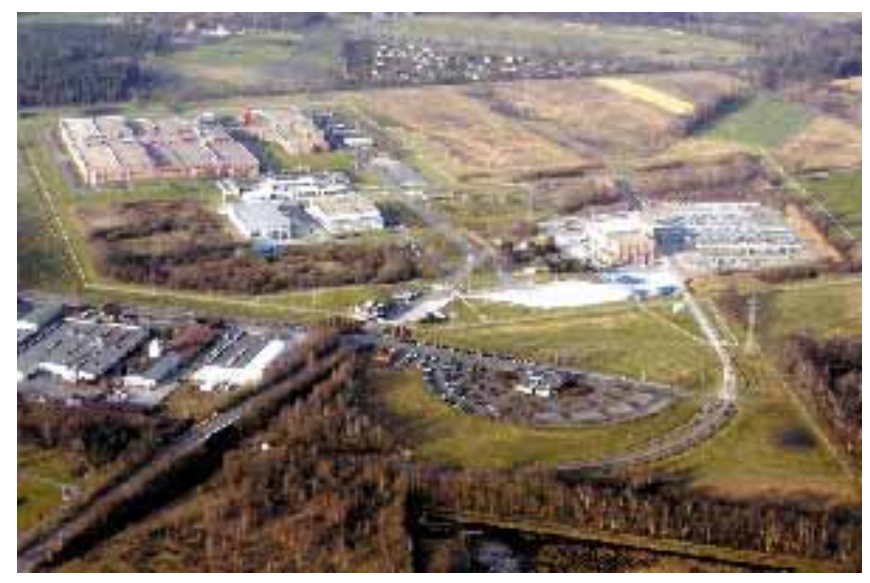

Fig. 18. Urenco Gronau, Germany. Source: kernenergie.de

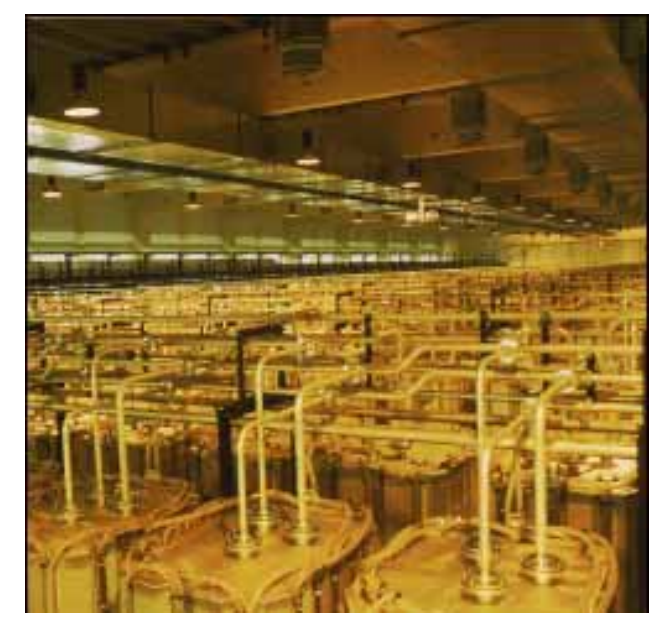

Fig. 19. Block-mounted centrifuges, Gronau. Source: U.S. DOE

\subsection{NETHERLANDS}

Construction of the initial pilot plants at Almelo (designated SP1 and SP2) began in 1972, and the first delivery of enriched $\mathrm{UF}_{6}$ was accomplished in 1976 . These pilot plants had an approximate capacity of 25,000 SWU/year. A 200,000 SWU/year demonstration plant (SP3) was built between 1974 and 1980. These three initial plants have been decommissioned. Since 1979, construction has proceeded on two larger facilities, SP4 and SP5 (Fig. 20). The current total capacity is 3,500,000 SWU/year, and Urenco has applied to expand the capacity of Almelo to 4,500,000 SWU/year. Unlike the Urenco GCEP at Gronau, the Almelo facilities use individually mounted centrifuges (Fig. 21).

The Netherlands was a participant in the HSP and have accepted the HSP safeguards measures in their facilities since around 1983. Following Program 93+2, they began accepting ES as part of the agreedupon Part 1 measures. Reportedly, there is no on-line enrichment monitoring at Almelo, but the Netherlands does allow LFUA walkthroughs. ${ }^{45}$ 


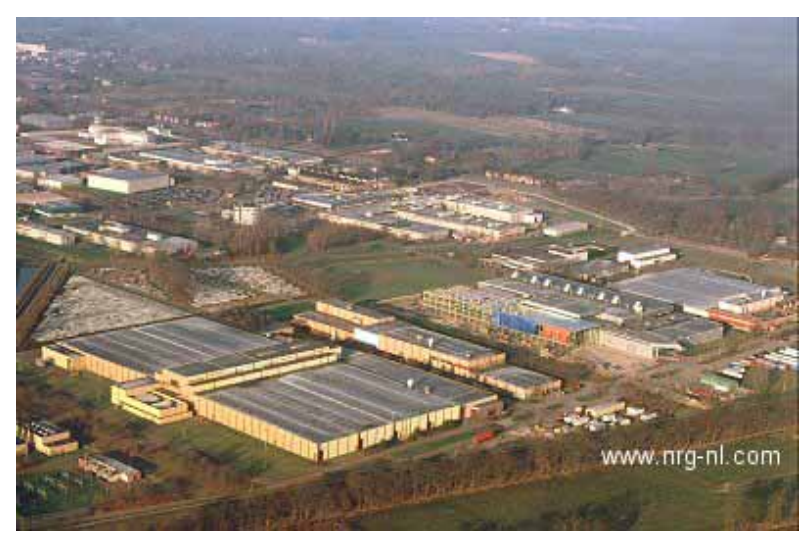

Fig. 20. Urenco Almelo, Netherlands. Source: nrg-nl.com

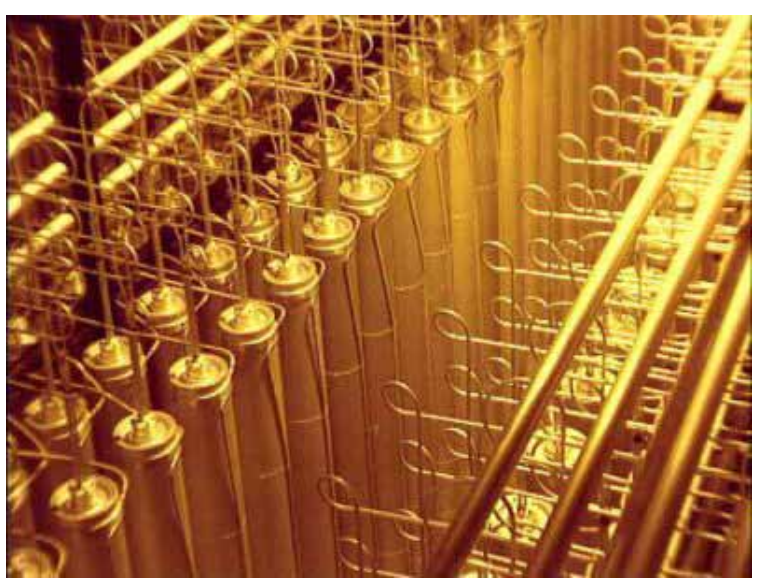

Fig. 21. Urenco centrifuges, Almelo.

Source: world-nuclear.org

\subsection{JAPAN}

The Power Reactor and Nuclear Fuel Development Corporation of Japan (PNC) began operating a pilot gas centrifuge facilities at Ningyo-Toge in 1979. PNC became the Japan Nuclear Cycle Development Institute (JNC) in 1998 and was merged into the Japan Atomic Energy Agency (JAEA) in 2005. The Ningyo-Toge pilot facility had a nominal capacity of 50,000 SWU/year and was shut down in 1990. Two 100,000 SWU/year demonstration plants began operating at the site in June 1988 and completed operation in March 2001. ${ }^{46}$ These facilities are being dismantled centrifuge-by-centrifuge, with individual components decontaminated to reduce radioactive waste volume and destroyed to protect sensitive design information. ${ }^{47}$ In addition, various laboratory-scale enrichment facilities involving gas centrifuge, AVLIS, and MLIS technology have been operated, shut down, and dismantled, mostly at Tokai. $^{48}$

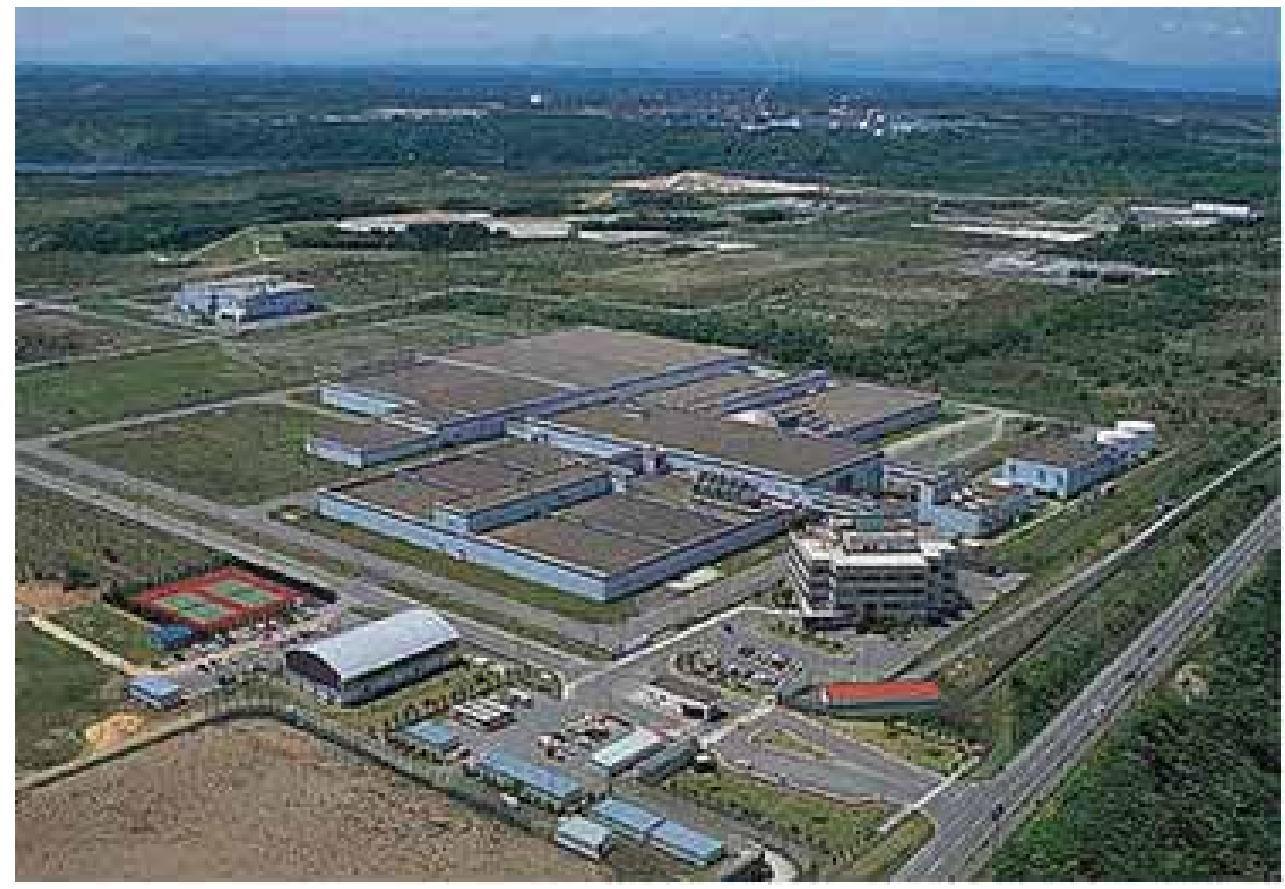

Fig. 22. Rokkasho Uranium Enrichment Plant, Japan.

Source: japannuclear.com 
The gas centrifuge facility in Rokkasho-mura, the Rokkasho Uranium Enrichment Plant (Fig. 22), was built by Japan Nuclear Fuel Limited (JNFL). Construction began in October 1988, and the initial unit began operation in 1992 with a capacity of 150,000 SWU/year. Six additional units have come online to increase the total capacity to 1,050,000 SWU/year. Currently, only two of the modules are operating (300,000 SWU/year) due to problems with the centrifuges, ${ }^{49}$ which are not being repaired since they are scheduled to be replaced anyway. The production capacity is targeted to increase to 1,500,000 SWU/year using advanced centrifuges with carbon fiber-composite rotors. ${ }^{50}$ In April 2007, JNFL announced the start of cascade tests of its advanced centrifuge design. Production using the advance centrifuges is slated to begin in $2010 .^{51}$ The Japanese were participants in the HSP and have implemented all of the HSP measures, as well as additional measures such as ES inside the cascade halls, at their demonstration and commercial facilities. $^{52}$

\subsection{AUSTRALIA}

The Australian Atomic Energy Commission (AAEC), the predecessor to the Australian Nuclear Science and Technology Organisation (ANSTO) had a gas centrifuge research and development program in the 1970s and 1980s and was a participant in the HSP. Bench-top cascade operation was achieved at the Lucas Heights Science and Technology Centre (Fig. 23), but the program was terminated in 1983 with no pilot plant built. ${ }^{53}$ When the centrifuge program was terminated, Australia decided to deny the IAEA access to the dismantled centrifuge components, on the basis of protecting proprietary technology. All blueprints, scientific reports, and components relating to the centrifuge program remain securely stored at Lucas Heights. As part of the 93+2 program, the IAEA was allowed limited access to the components for verification purposes. In addition, the buildings that housed the centrifuge program were used as an early testbed for IAEA environmental sampling techniques:

The buildings had been cleaned out, decontaminated and repeatedly repainted in the 10 year period before sampling took place. While these activities had been part of a normal pattern of building reassignment and usage in the case of Australia's declared program, the activities were similar in nature to the steps a proliferator might use to conceal the existence of a clandestine program. IAEA ES had no difficulty in determining the location within the building of the various aspects of centrifuge work. The IAEA was also able to determine the average enrichment level that was achieved during the research project and the maximum level of enrichment achieved. ${ }^{54}$

However, the technology and expertise for centrifuge enrichment is still present, and the Australian government is said to be considering re-launching a uranium enrichment program in the country for the purpose of "value-adding" to its current uranium exports, but no actions have been taken at this point. ${ }^{55}$

Australia is also developing a laser isotope separation process called SILEX (separation of isotopes by laser excitation), a variation of MLIS, at Lucas Heights. Silex Systems Limited and GE-Hitachi are constructing a "Test Loop" of the SILEX laser enrichment process in Wilmington, NC. In August 2007, Silex announced "the successful completion of the transfer of our uranium enrichment project from our Lucas Heights facility to GE's Nuclear Fuel Plant in Wilmington North Carolina." 56 The application of this technology in the United States is discussed in the section on the U.S. enrichment program. 


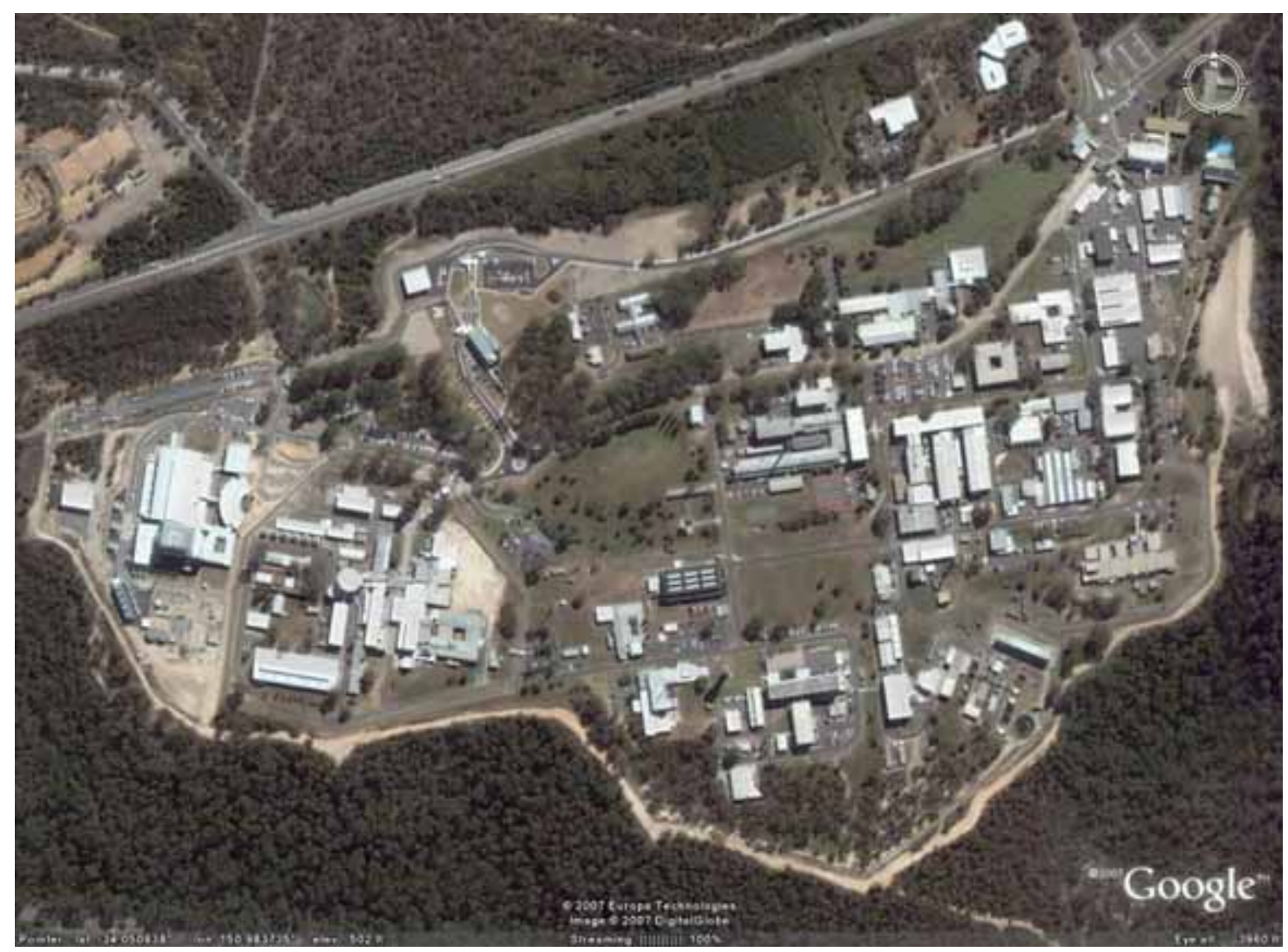

Fig. 23. Lucas Heights Science and Technology Centre, Australia.

Source: Google Earth

\section{OTHER NPT STATES}

Several other states have enrichment facilities, although none are currently large enough to produce surplus LEU for export. South Africa and Argentina have enrichment facilities that are shutdown, although Argentina has announced plans to resume enrichment activities at its plant. Brazil and Iran are both constructing moderate-size GCEPs that are reportedly intended to provide LEU for their own power reactors, and both plants are safeguarded by the IAEA.

Brazil and Argentina formed the bilateral Brazilian-Argentine Agency for Accounting and Control of Nuclear Materials (ABACC) in 1991 as "an entity responsible for verifying that the nuclear materials existing in both countries are being used for exclusively peaceful purposes." implement safeguards measures at the nuclear facilities in both states; Brazil and Argentina also signed a Quadripartite Agreement with ABACC and the IAEA in 1991 to coordinate safeguards activities and avoid duplicate inspections by the two agencies. ABACC is responsible for coordinating the analysis of environmental samples at laboratories in Brazil and Argentina, ${ }^{58,59}$ and is working to optimize HSP safeguards techniques for the lower-capacity centrifuge enrichment facilities under its jurisdiction. ${ }^{60}$

States have also done laboratory-scale experiments in uranium enrichment, although no production facilities were planned or built. In 2004, the Republic of Korea disclosed as part of its Additional Protocol declaration that in 2000 government scientists had performed unauthorized enrichment of uranium during a larger project of enriching stable isotopes with an AVLIS process. ${ }^{61}$ The experiments produced about 200 milligrams of uranium enriched up to $77 \%{ }^{235} \mathrm{U}^{62}$ 


\subsection{BRAZIL}

Brazil has two operating pilot gas centrifuge facilities at the Aramar Experimental Center, located about 100 kilometers west of Sao Paulo (Fig. 24). The total capacity of these two plants is reported to be about 9,000 SWU/year. ${ }^{63}$ A commercial enrichment facility is under construction at a site near Resende (Fig. 25), located about 100 kilometers from Rio de Janeiro. The Resende site also contains a fuel-fabrication facility and a $\mathrm{UF}_{6}$-to- $\mathrm{UO}_{2}$ uranium conversion plant. The enrichment plant is being constructed by stateowned Indústrias Nucleares do Brasil (INB), which signed a contract with the Brazilian navy in 2000 to use navy-designed centrifuges. ${ }^{64}$ The first module, which will eventually contain four cascades, now has one cascade operating and a second under construction. $\mathrm{UF}_{6}$ was introduced into the first cascade in early 2005. The first unit was officially inaugurated by the Ministry of Science and Technology in May $2006 .{ }^{65}$ The plant is expected to be operating at full capacity (four modules of four cascades each, for a total of approximately 120,000 SWU/year) by 2015. This will be enough enrichment capacity to provide about half of the yearly requirement of LEU fuel for Brazil's existing power reactors, Angra-I and -II.

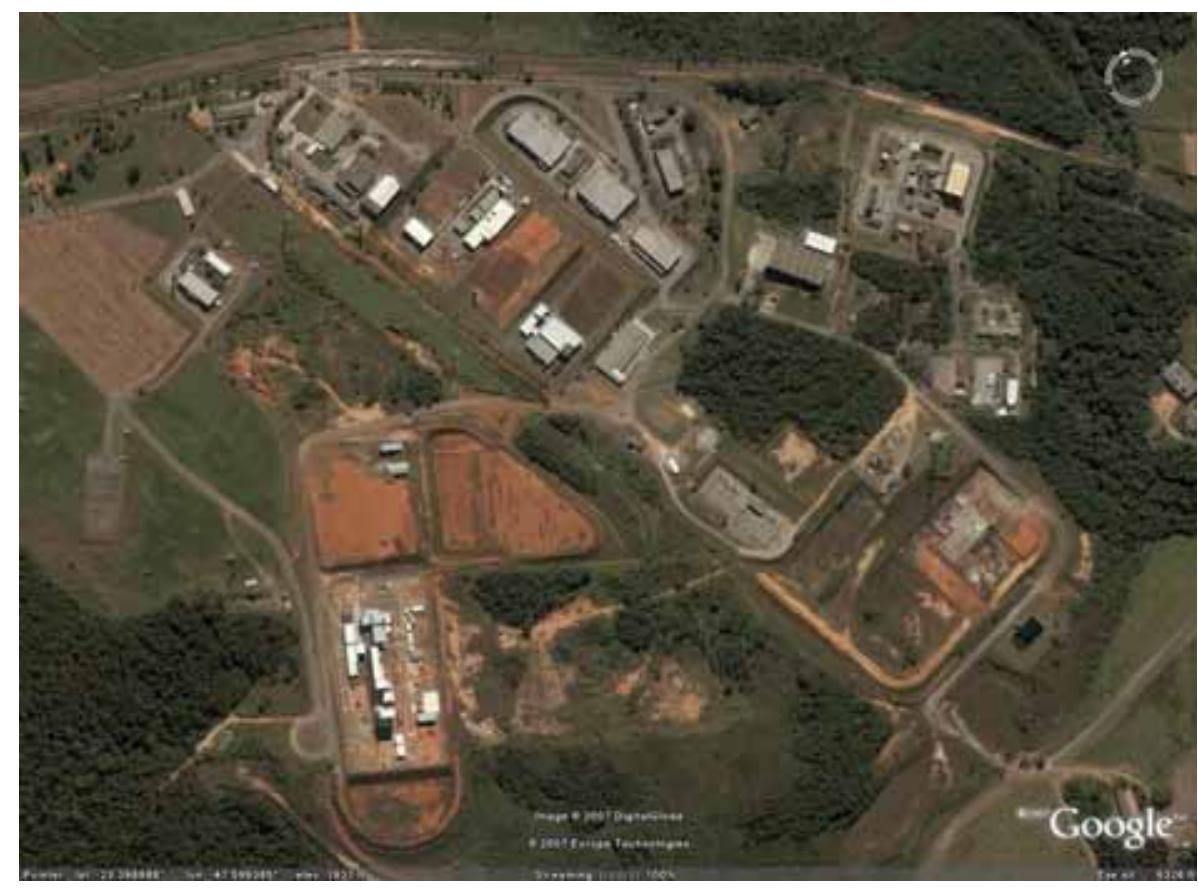

Fig. 24. Aramar Experimental Center, Brazil.

Source: Google Earth

The specific safeguards approach for the Resende plant was under negotiation for a number of years. Brazil is concerned with restricting access to proprietary information about its centrifuge design, which reportedly has two proprietary active magnetic bearings, top and bottom, instead of the usual one in other commercial centrifuge designs. ${ }^{66}$ Differences centered on whether IAEA inspectors would be allowed full visual access within the cascade hall or whether Brazil would be allowed to keep the equipment shrouded. Brazil and the IAEA finally reached agreement on the safeguards approach in the fall of $2004{ }^{67}$ Under the agreed-upon approach, IAEA inspectors are not permitted to remove visual information about the cascades at Resende and Aramar. The inspectors are allowed to have limited visual access to the cascades and compare what they see to a validated set of baseline photographs held by the operator under IAEA seal. The compromise, which also allowed Brazil to shroud access to the bearings in the first module, applies only to this first stage of operation at Resende. The agreement will be re-negotiated and the casings redesigned for safeguarding the full-capacity plant. 


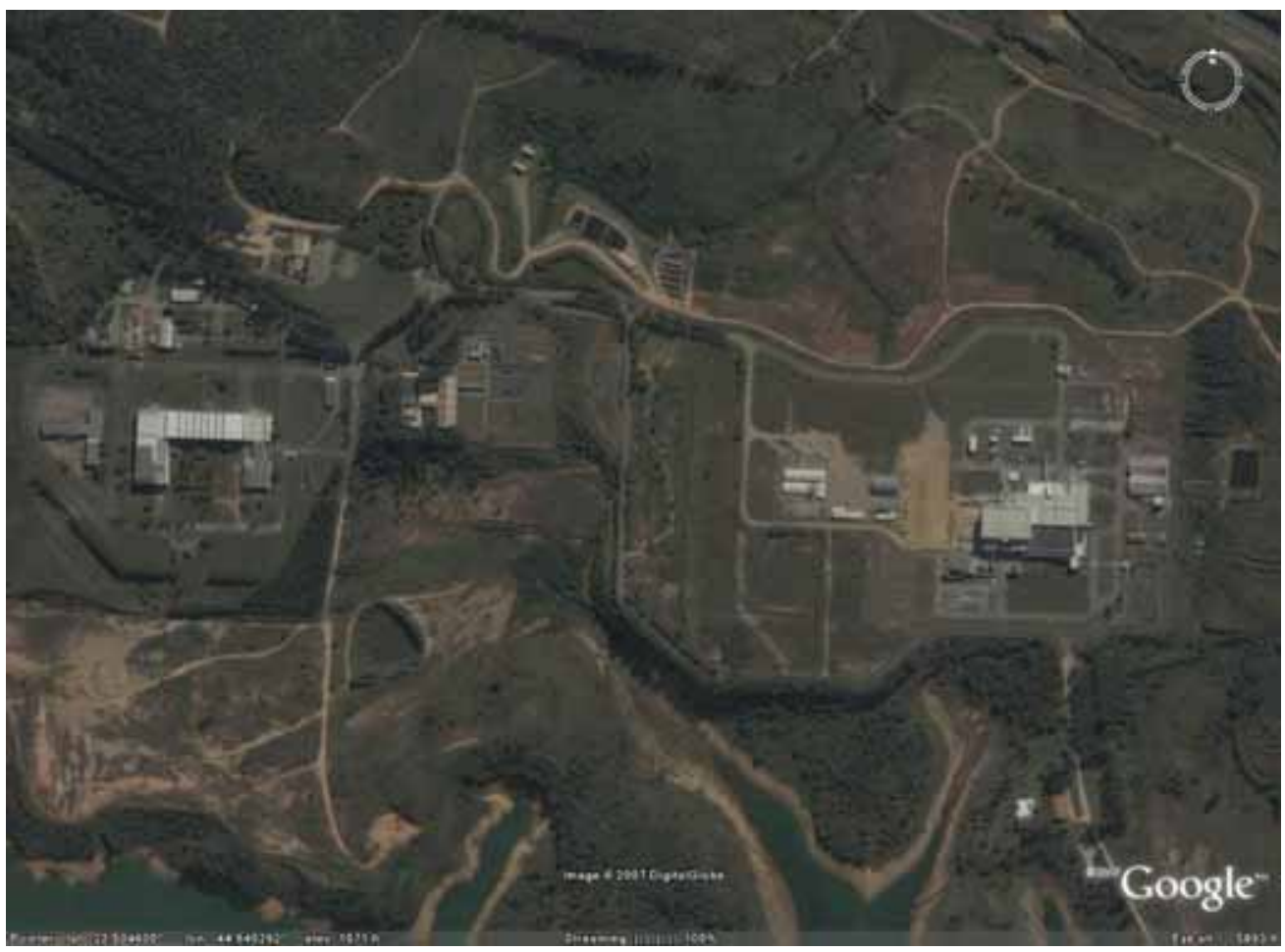

Fig. 25. Resende Nuclear Fuel Facility, Brazil. $\quad$ Source: Google Earth

At Aramar, ES is permitted only for cylinders and the feed and withdrawal (F/W) stations. At Resende, ES is also allowed inside the cascade hall. All inspections are essentially unannounced inspections (UIs) with full access to F/W stations and the results of destructive assay (DA) measurements. NDA inside the cascade halls is not considered in the approach at Resende; however, the IAEA has been permitted to take supplemental NDA measurements at Aramar to compensate for the lack of complete visual access.

The Brazilian president recently announced funding to complete construction of the Angra-3 reactor, and emphasized that one of the aims of the country's nuclear program is to design, build, and fuel a nuclear submarine. ${ }^{68}$

\subsection{ARGENTINA}

In the late 1970s through early 1980s, when Argentina was under military rule and before it acceded to the NPT, it began a secret program to develop indigenous gaseous diffusion technology. The existence of this technology, and the gaseous diffusion enrichment plant built at Pilcaniyeu (Figs. 26, 27) in the Rio Negro province, were successfully concealed until the government of President Raúl Alfonsin revealed them, shortly after the restoration of civilian rule.

Plant operation at Pilcaniyeu was suspended in the late 1980s with the intention to restart it after some upgrades were completed. With the signing of the Quadripartite Agreement in 1994, the facility became subject to full scope safeguards. Although not operating, the IAEA still had to verify the material inventory. Since this was the first gaseous diffusion plant subjected to IAEA safeguards, the Agency needed a method to verify the in-process cascade inventory. Cascade inventory verification had not been a significant concern for centrifuge plants because the process inventory of a GCEP is on the order of a thousand times smaller than that for a GDP. After the inventory was verified with assistance from the U.S. Support Program, the IAEA continues to verify that the status of the plant is unchanged and the plant has not operated. 


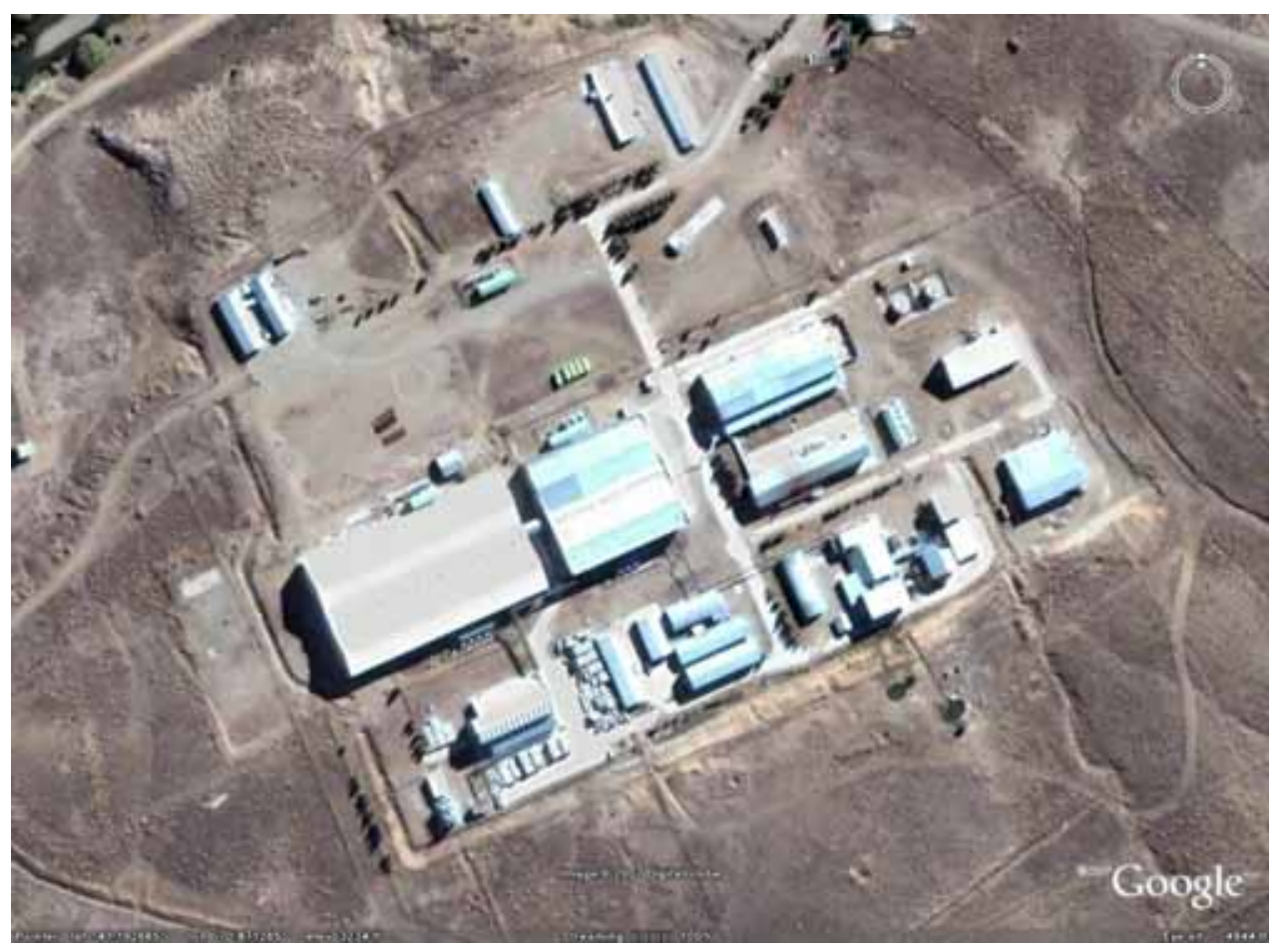

Fig. 26. Pilcaniyeu, Argentina. Source: Google Earth

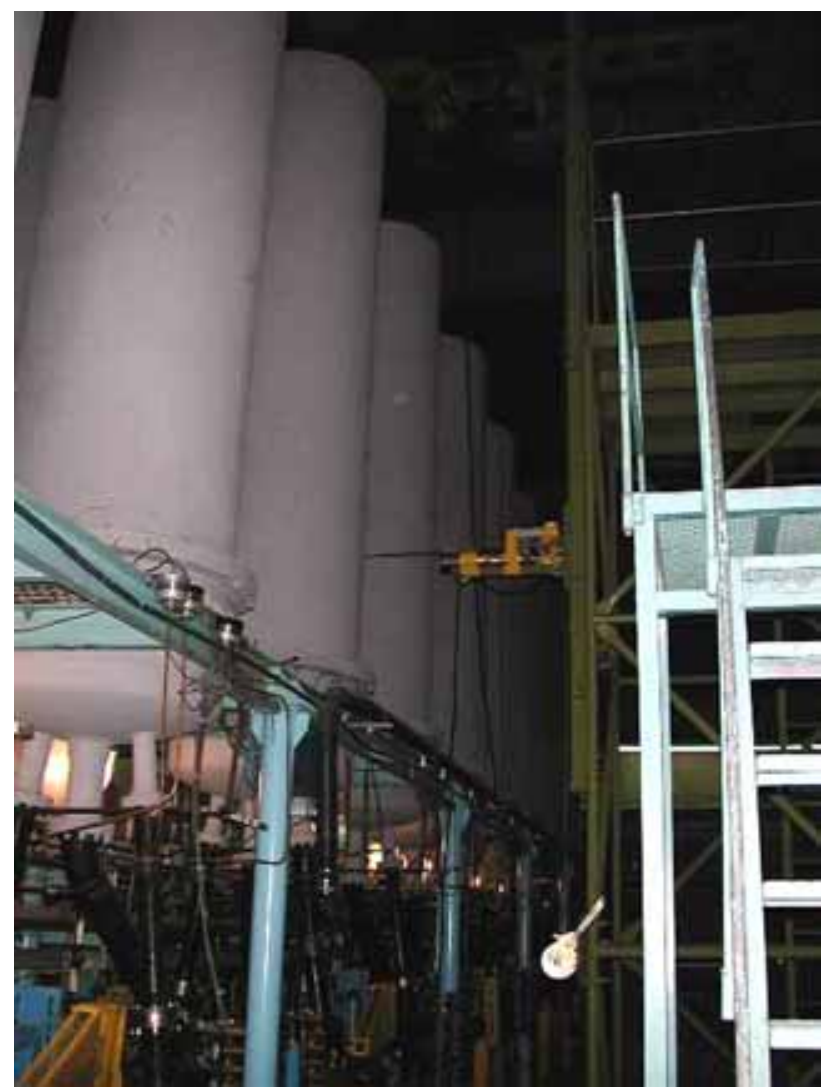

Fig. 27. Argentine diffusers, Pilcaniyeu.

Source: Whitaker, $2005^{69}$ 
Reportedly, the initial planned capacity was 20,000 SWU/year with longer-term plans to expand to $100,000 \mathrm{SWU} /$ year. A portion of the cascade was completed in the mid-1980s, but the plant has never operated well due to problems with short barrier life, leaking seals, and compressor reliability. The cascade consists of 20 units with 20 stages each (400 stages total). During its operation, Argentina produced only small amounts of LEU. In 1989 the cascade was shut down, and a new 20-stage pilot plant with improved technology was opened in December 1993. Renovation of the older plant, to be operated under safeguards, was subsequently undertaken but progress was slow and was plagued with long periods of inactivity.

On August 23, 2006, however, Planning Minister Julio De Vido announced that Argentina is going to expand its nuclear program, including completion of the Atucha 2 and CAREM reactors and reactivation of its uranium enrichment capability at Pilcaniyeu, initially reported to begin sometime in $2007 .{ }^{70}$

According to one report, Argentina now plans to enrich uranium up to 5 percent ${ }^{235} \mathrm{U}$. It has been reported that one of the reasons for resuming enrichment is to establish Argentina's place as an enrichment supplier country. Canada announced in July of 2007 that it had reached a preliminary agreement with Argentina on supplying a new CANDU reactor beyond Atucha 2. ${ }^{71}$

\subsection{SOUTH AFRICA}

South Africa constructed and operated two enrichment plants at Pelindaba (Fig. 28): one to produce HEU for a weapons program ("Y-Plant") and a second semi-commercial plant to produce LEU ("Z-Plant"). Both plants used a unique aerodynamic enrichment method called the Helikon vortex separation process. The Helikon process requires large amounts of electricity and produces a lot of waste heat, making it uneconomical as a commercial enrichment process. Using HEU from Y-Plant, South Africa assembled six gun-type nuclear weapons, and a seventh was being constructed when the country revealed the program and began to dismantle its weapons program. ${ }^{72}$ The HEU plant was shut down prior to South Africa acceding to the NPT in 1991, and the IAEA applied safeguards to the semi-commercial plant until it was shut down in $1995 .^{73}$ In 1994, the IAEA confirmed that South Africa's nuclear weapons program had been completely terminated and dismantled. ${ }^{74}$

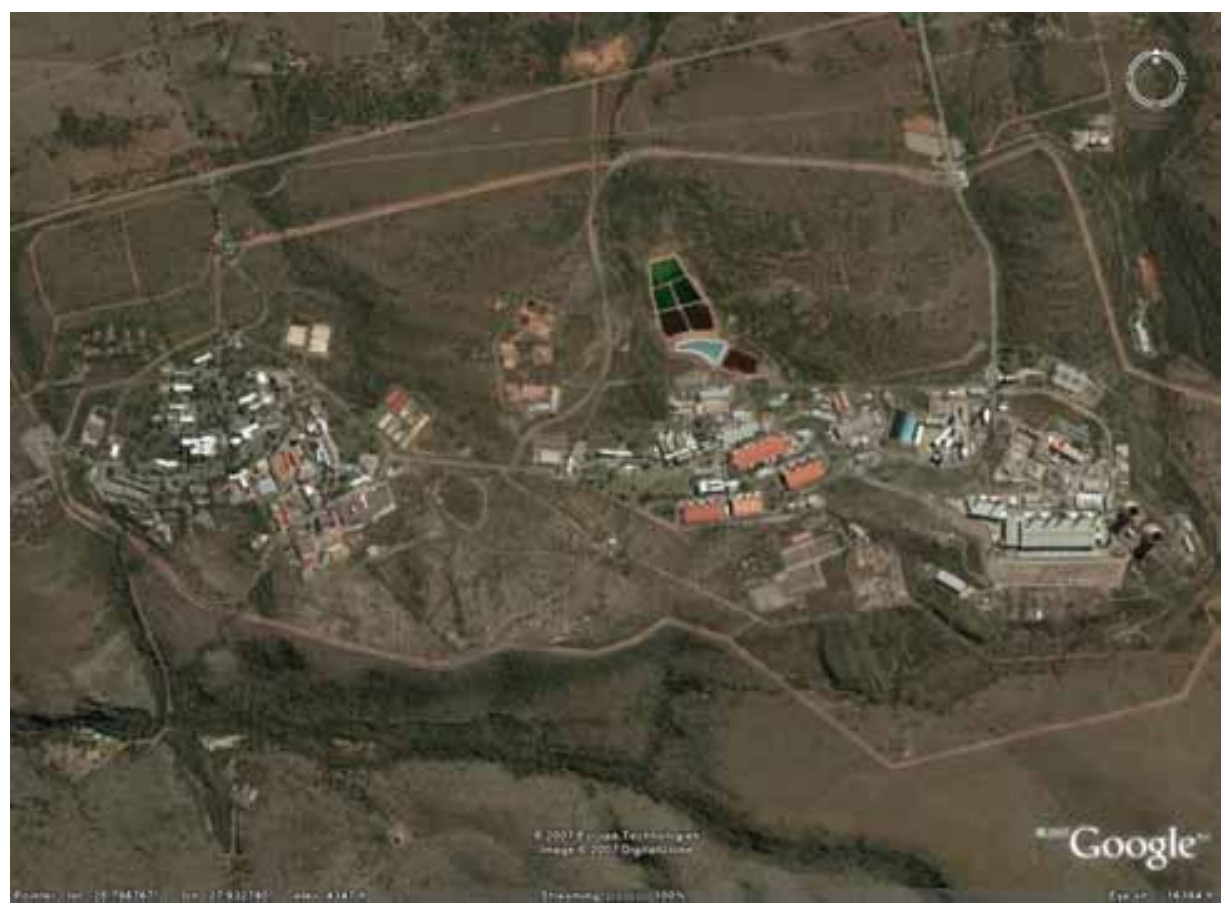

Fig. 28. Pelindaba, South Africa.

Source: Google Earth 
In August 2006, the Minister of Minerals and Energy said that South Africa would conduct a cost-benefit study on reviving the country's enrichment program (uranium "beneficiation”) as part of a larger effort to expand its nuclear power industry. ${ }^{75}$ A draft of South Africa's nuclear energy policy, released for public comment in July 2007, states that the "Government's strategic intent is to develop national capacity in uranium enrichment as part of uranium beneficiation. Government, through the Nuclear Energy Corporation of South Africa (NECSA), shall investigate the viability of developing its own uranium enrichment capabilities and will simultaneously actively seek to acquire established uranium enrichment technologies to ensure security of supply."76

\subsection{IRAQ}

Iraq began investigating clandestine uranium enrichment for a nuclear weapons program after the bombing of the Osirak reactor by Israel in 1981 conveyed the need to pursue parallel fissile material programs (plutonium production and uranium enrichment). Iraqi scientists chose to primarily pursue EMIS technology in the near term, with gaseous diffusion as a backup and to produce LEU feedstock for the EMIS program, and gas centrifuge enrichment as a longer-term goal. Some preliminary research also took place on laser enrichment. Construction began on the first EMIS facility in 1987. Progress on both EMIS and diffusion was slow, and in 1988 officials decided to de-emphasize diffusion and concentrate more on centrifuges. According to David Albright of the Institute for Science and International Security (ISIS), who conducted interviews with Iraqis and Germans involved with the program, Iraq received illicit assistance from German centrifuge experts. ${ }^{77}$ They also pursued chemical enrichment as another LEU feedstock provider for EMIS. The 1990-1991 Gulf War and especially the bombing campaign against Iraq in January 1991 brought the program to a halt. At this point, the Iraqi enrichment program had only succeeded in producing a few grams of uranium enriched to slightly over $20 \%{ }^{235} \mathrm{U}$. IAEA inspections of Iraq's nuclear facilities began in the summer of 1991, after the war ended (Figs. 29, 30). ${ }^{78}$ Inspections continued until inspectors were withdrawn in December 1998, amid continuing international suspicion that Iraq was continuing parts of its nuclear program; IAEA inspections resumed in November 2002. ${ }^{79}$ After the March 2003 invasion of Iraq by the United States, U.S. inspectors attempted to secure all known Iraqi nuclear materials and facilities. ${ }^{80}$

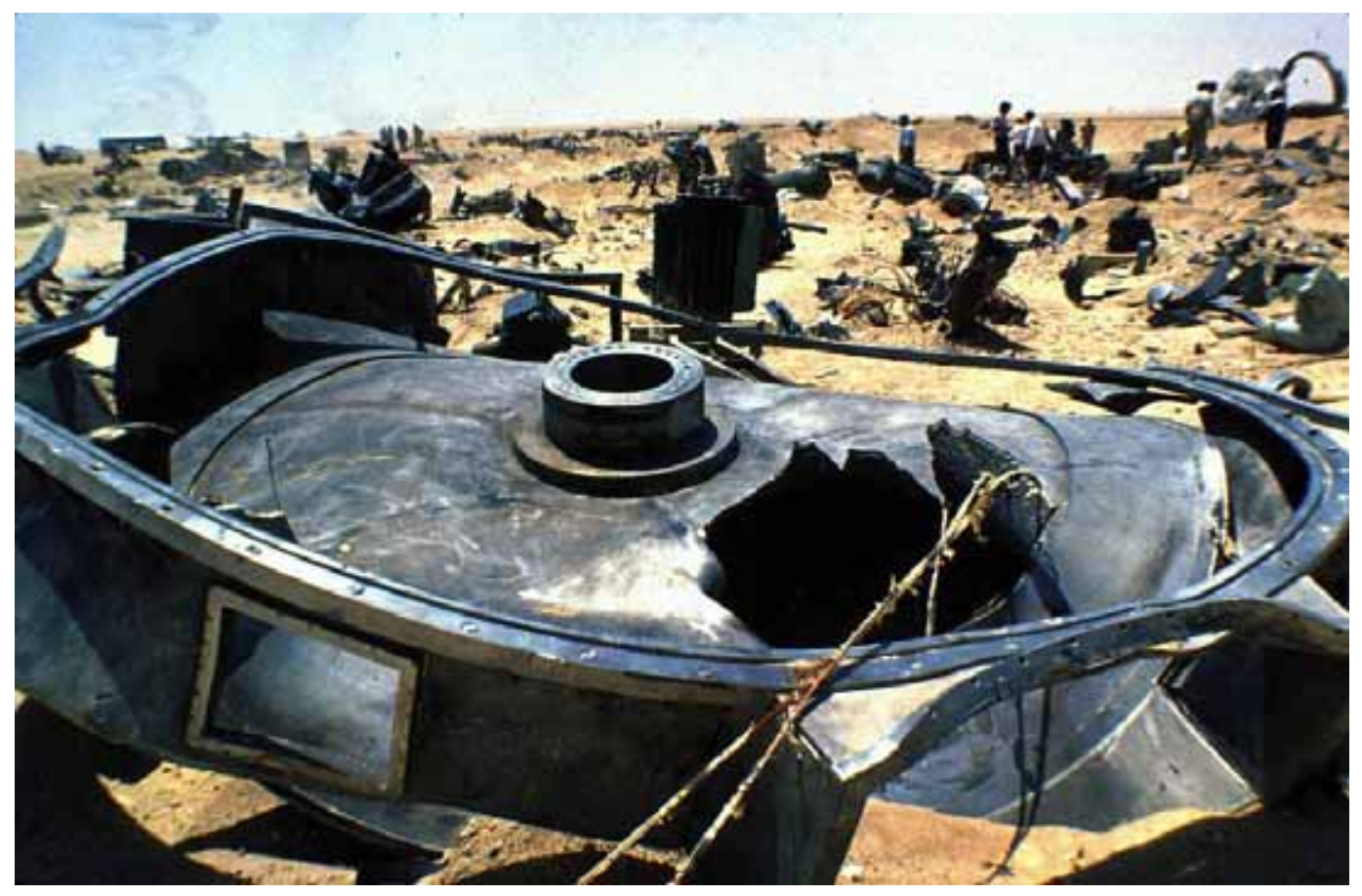

Fig. 29. Calutron wreckage in Iraq in the 1990s.

Source: fas.org 


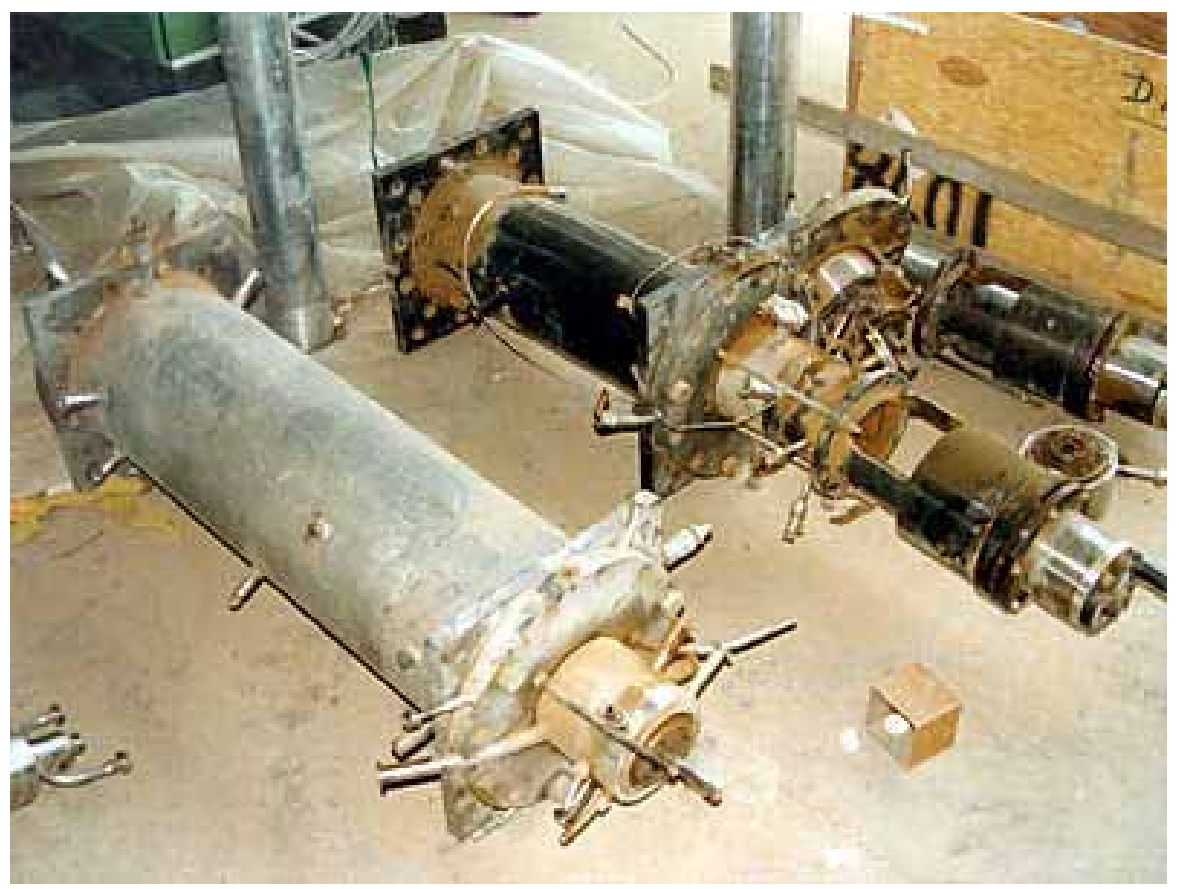

Fig. 30. Centrifuges discovered in Iraq by IAEA inspectors in the 1990s. Source: iaea.org

\subsection{LIBYA}

In December 2003 Libya publicly revealed and renounced its nuclear weapons program. IAEA inspection teams were in Libya by the end of the month, and IAEA and foreign experts worked with Libya to thoroughly verify its declaration and secure the nuclear material and equipment. In March 2004, Libya signed an Additional Protocol with the IAEA. ${ }^{81}$

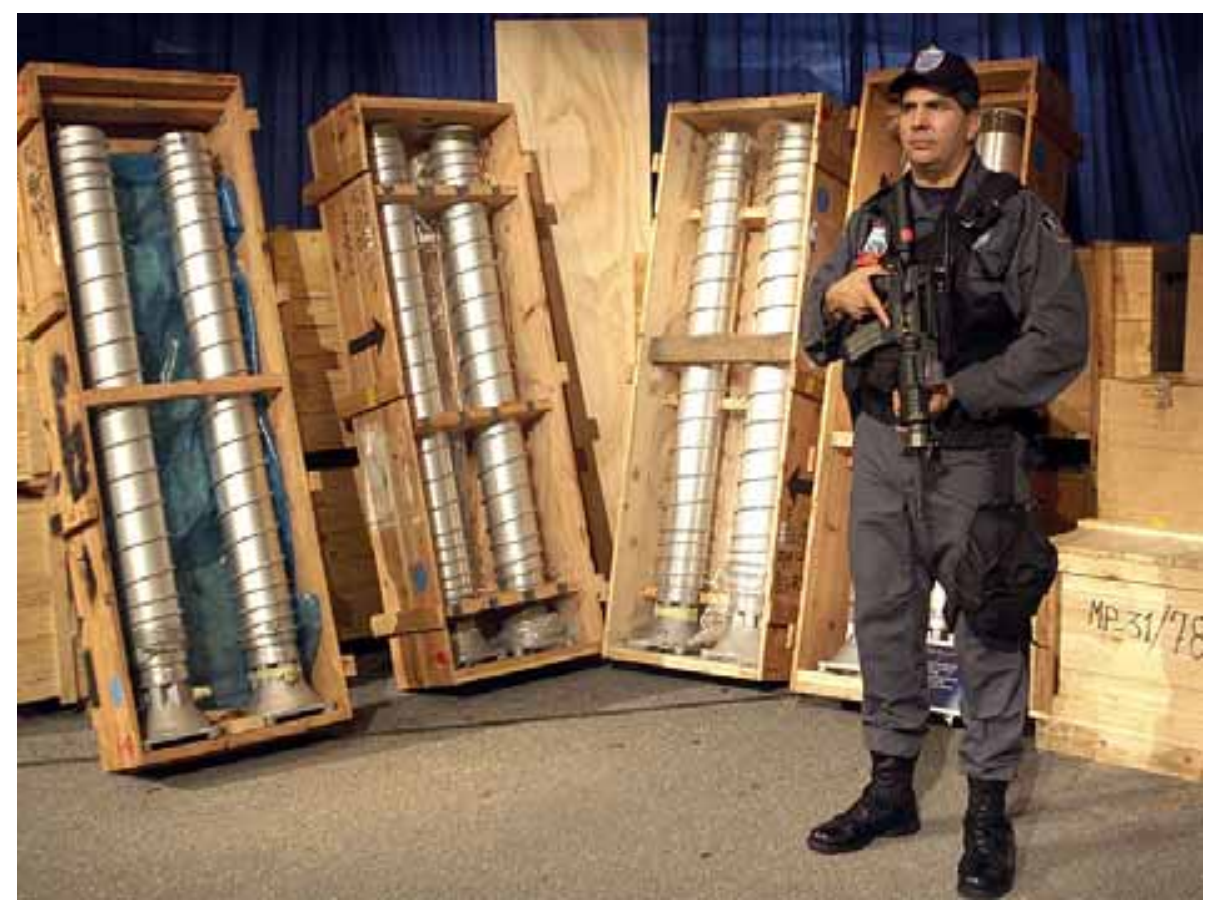

Fig. 31. Libyan centrifuge casings. 
Libya based its enrichment program on equipment and information obtained through the A.Q. Khan network. The IAEA reports that in the late 1990s and early 2000s, Libya obtained 20 complete L-1 (or P-1) centrifuges and 2 complete L-2 (or P-2) centrifuges through the network, as well as at least some of the parts necessary for 200 additional L-1 and 10,000 additional L-2 centrifuges, largely produced at a factory in Malaysia under the direction of A.Q. Khan associates. ${ }^{82}$ By 2002 several small test cascades had been partially constructed but never operated, and these were all dismantled and put into storage by the time of Libya's declaration. ${ }^{83}$ Much of Libya's centrifuge equipment and nuclear material, including four cylinders of $\mathrm{UF}_{6}$, was transported in January 2004 to the Y-12 National Security Complex in Oak Ridge for storage (Fig. 31). ${ }^{84,85}$

\subsection{IRAN}

It was revealed to the public in 2002 that Iran was constructing a centrifuge plant for uranium enrichment at Natanz, south of Tehran, as well as a heavy water production plant at Arak. ${ }^{86}$ The Natanz facility (Figs. 32, 33) includes a small Pilot Fuel Enrichment Plant (PFEP) with two 164-centrifuge cascades and several smaller test cascades, and a full-scale underground Fuel Enrichment Plant (FEP) designed for approximately 50,000 centrifuges and an estimated total capacity of 250,000 SWU/year. ${ }^{87}$ The facility is overseen by the Atomic Energy Organization of Iran (AEOI). The designs for the centrifuges at Natanz as well as many centrifuges and centrifuge components were supplied to Iran by the A.Q. Khan network.

Iran has been enriching small amounts of uranium at the PFEP since April 2006, and construction and installation of the first module of centrifuges is continuing at the FEP. As of the August 2007 Director General's report to the IAEA Board of Governors, Iran was enriching uranium in twelve 164-centrifuge cascades at the FEP, operating one cascade without $\mathrm{UF}_{6}$, vacuum-testing one, and installing two more. Since operation at the FEP began in February 2007 until the IAEA report in August, Iran had fed approximately 690 kilograms of natural $\mathrm{UF}_{6}$ into the cascades, and ES by the IAEA had verified the production of uranium enriched up to $3.7 \%{ }^{235} \mathrm{U}$. The IAEA is continuing to implement safeguards, including unannounced inspections and containment and surveillance measures, at the facilities at Natanz..$^{88,89}$ 


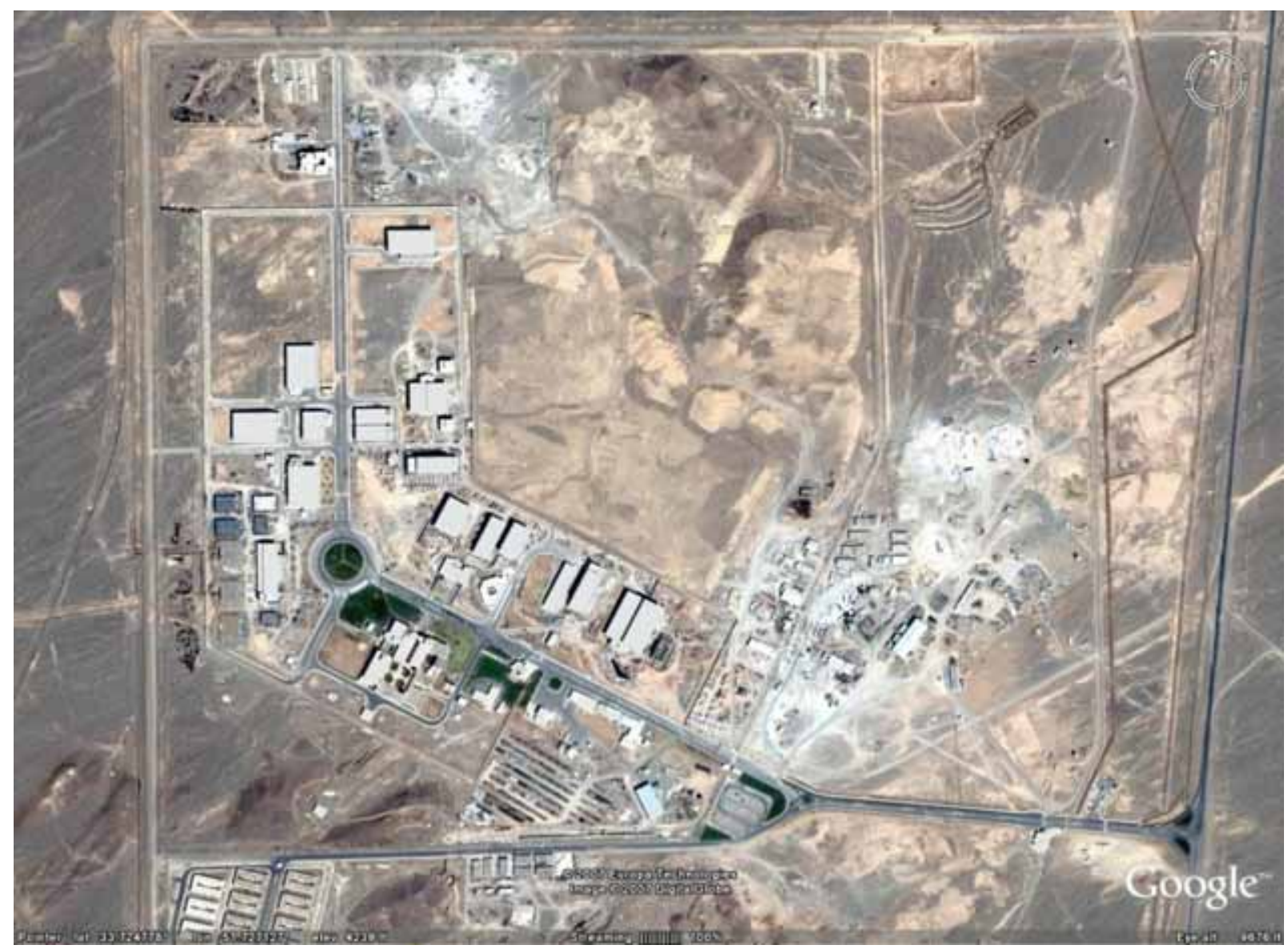

Fig. 32. Natanz, Iran.

Source: Google Earth

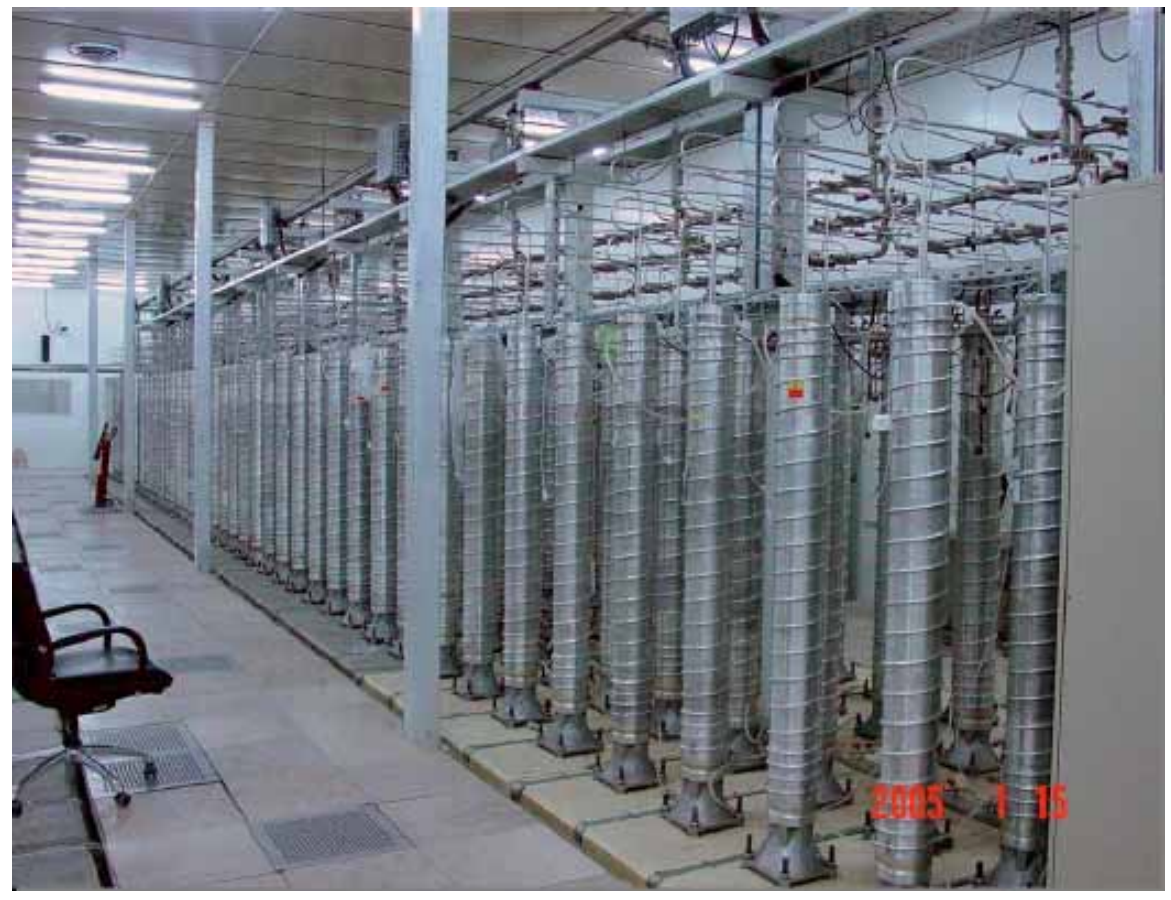

Fig. 33. 164-centrifuge cascade at the Natanz PFEP, Iran.

Source: Wood $^{90}$ 


\section{NON-NPT STATES}

Two states that are not parties of the Non-Proliferation Treaty (NPT), India and Pakistan, are known to have developed enrichment capabilities. Both have tested nuclear devices, although only Pakistan is believed to utilize uranium enrichment as a key component of its nuclear weapons program.

There have been reports that the Democratic People’s Republic of Korea (DPRK, "North Korea”) has been developing a clandestine enrichment capability as part of a nuclear weapons program. An unclassified 2002 U.S. National Intelligence Estimate said that DPRK had done at least research and development for an HEU project, and subsequent unclassified intelligence reports to the U.S. Congress stated that DPRK was constructing a full-scale enrichment facility. ${ }^{91}$

In an interview with NPR in March 2007, Christopher Hill, Assistant Secretary of State for East Asian and Pacific Affairs and head of the U.S. delegation to the Six Party Talks, stated that the United States continues "to assess that North Korea has attempted and succeeded in buying a number of parts to put together a uranium enrichment program. How far they got and whether they were successful in actually manufacturing highly enriched uranium, that's hard to say."

There continues to be a high level of uncertainty about the nature and extent of DPRK's uranium enrichment program, prompting questions and debate from non-governmental analysts and members of Congress. For example, Selig Harrison of the Center for International Policy wrote in Foreign Affairs in 2005 that the "administration presented a worst-case scenario as an incontrovertible truth and distorted its intelligence on North Korea."94 Former administration officials Mitchell Reiss and Robert Gallucci responded in the next issue of Foreign Affairs that "the case has been made and is credible."95 A February 2007 analysis from ISIS concluded that DPRK likely obtained centrifuge equipment from the A.Q. Khan network, but stated that it is not clear that an enrichment facility was ever built. ${ }^{96}$ In March 2007, U.S. Senator Carl Levin, Chairman of the Senate Armed Services Committee, wrote to the U.S. Secretaries of State and Defense asking for clarification of intelligence regarding DPRK's uranium enrichment program, after Congressional testimony by administration officials and media reports suggested that government officials were downplaying previous assessments. ${ }^{97}$

Israel, the final non-NPT state, is also widely believed to have nuclear weapons but these are largely thought to be plutonium weapons. A former Dimona technician, Mordechai Vanunu, leaked information and photographs of activities at Dimona to the British press in 1986, confirming that Israel had focused on constructing plutonium-based nuclear weapons. ${ }^{98}$ Israel may have laboratory-scale enrichment facilities at its Dimona nuclear complex. A 1974 CIA memorandum referred to the "ambiguous nature of Israeli efforts in the field of uranium enrichment."

\subsection{INDIA}

India began a nuclear weapons program in the 1960s over security threats from China and Pakistan. India's weapons program focused on plutonium production using heavy water "research reactors" at the Bhabha Atomic Research Centre (BARC) in Trombay, especially the Canadian-designed CIRUS reactor that began operation in 1960 (Fig. 34). Uranium enrichment has not played a large role in India's civilian nuclear program, either, since most of its power reactors are also heavy water reactors that use natural uranium fuel. India began operating a 100-centrifuge test cascade at BARC in 1985, and constructed a small GCEP called the Rattehalli Rare Materials Plant near Mysore in the late 1980s (Fig. 35). ${ }^{100}$ This plant is reportedly intended to produce HEU (with $30-45 \%{ }^{235} \mathrm{U}$ ) for a possible nuclear-powered submarine program. ${ }^{101}$ None of India's enrichment facilities are subject to safeguards. 


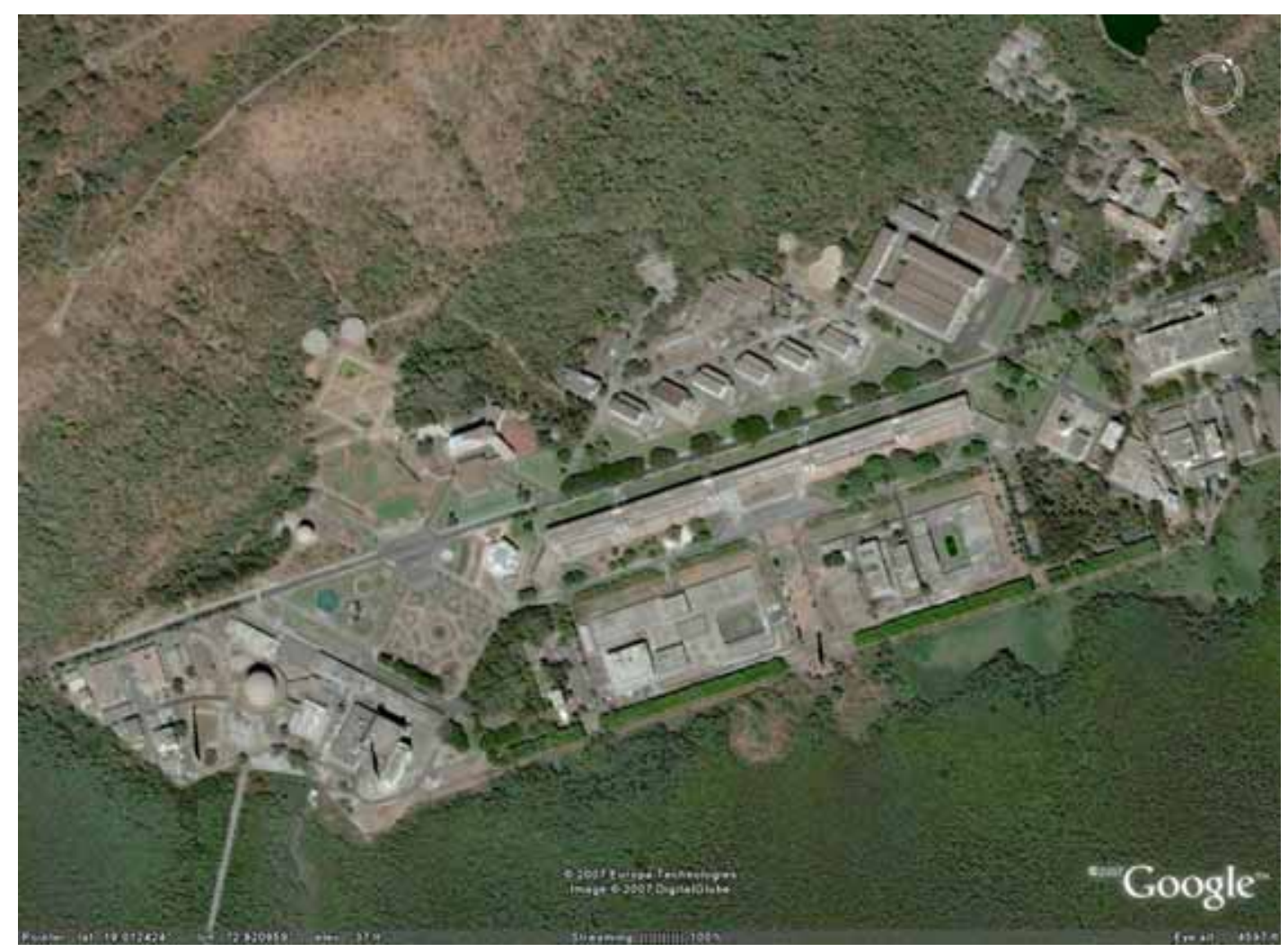

Fig. 34. Bhabha Atomic Research Centre, India.

Source: Google Earth

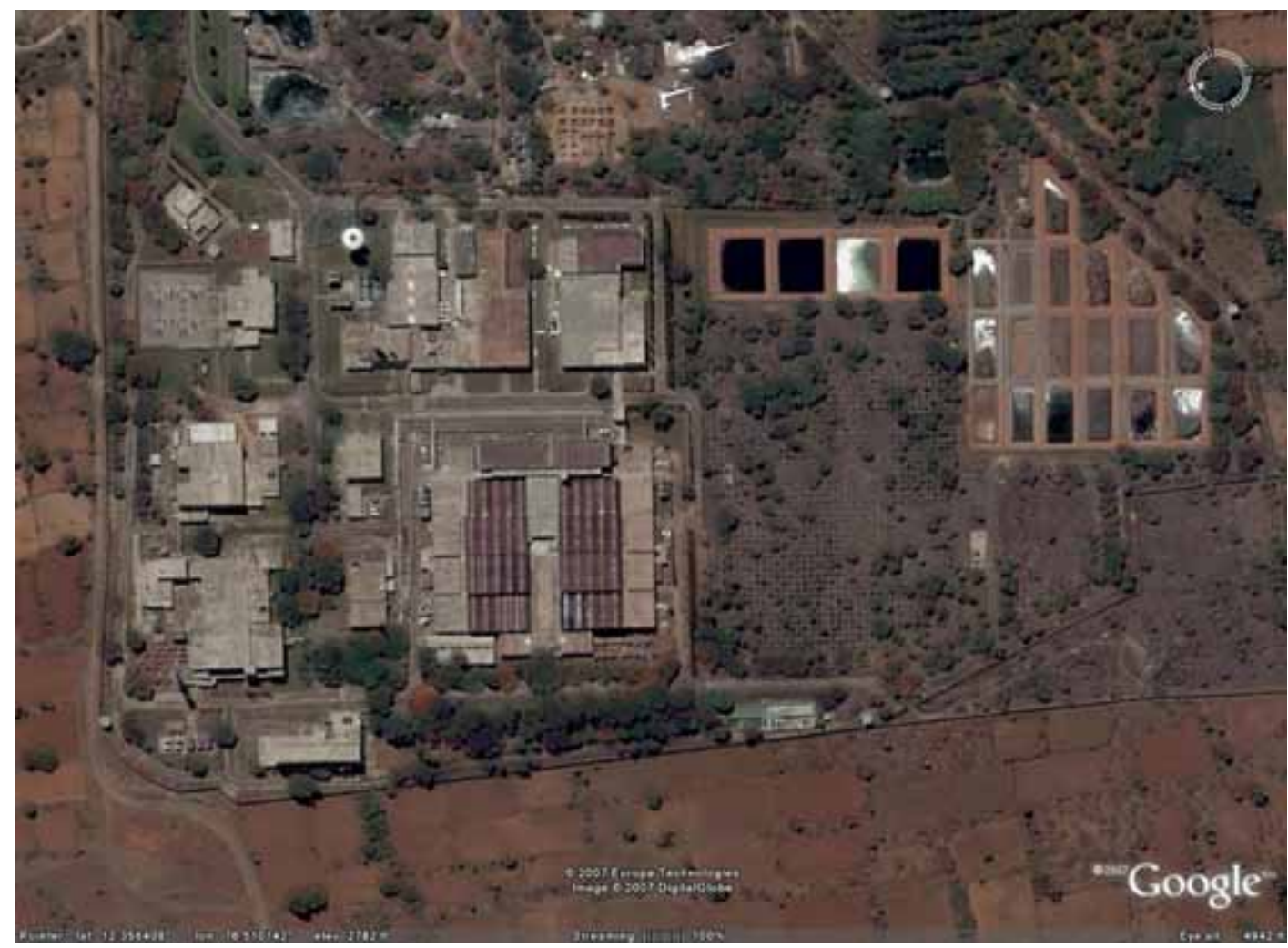

Fig. 35. Rattehalli Rare Materials Plant, India.

Source: Google Earth 


\subsection{PAKISTAN}

Pakistan began a nuclear weapons program in earnest in 1974 after India tested a nuclear device. While initially focusing on plutonium production through foreign-supplied reactors, the program shifted its attention to uranium enrichment after foreign suppliers pulled out and A.Q. Khan returned from the Netherlands in 1975. A.Q. Khan had worked for the Urenco subcontractor FDO (Fysisch Dynamisch Onderzoekslaboratorium) at Almelo ${ }^{102}$, and, when he came to Pakistan, he brought stolen centrifuge plans as well as contacts with centrifuge component suppliers, forming the basis of Pakistan's uranium enrichment program as well as the "Khan network," an international nuclear black market that supplied centrifuge technology to Libya, Iran, and DPRK. In Pakistan, Khan founded what became the Khan Research Laboratory (KRL) at Kahuta (Fig. 36), Pakistan's primary enrichment facility, overseen by the Pakistan Atomic Energy Commission (PAEC). The capacity of the GCEP at KRL is not well known; estimates range from 5,000 SWU/year up to over 100,000 SWU/year, ${ }^{103}$ while the general consensus is that the capacity is somewhere in the range of 15,000-20,000 SWU/year.

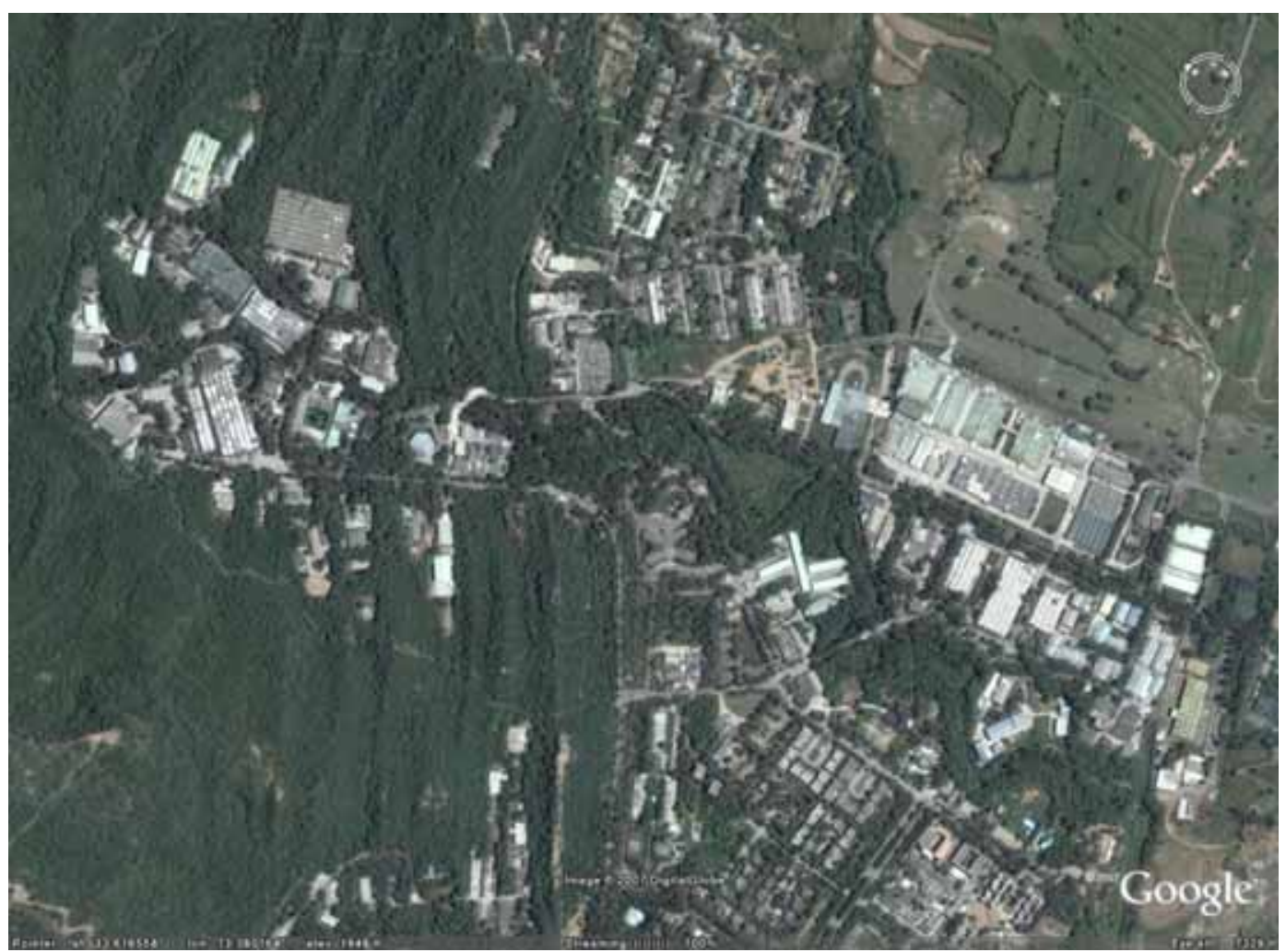

Fig. 36. Khan Research Laboratory, Kahuta, Pakistan.

Source: Google Earth

There have been unconfirmed reports since the 1980s that Pakistan may be constructing another GCEP at Golra Sharif outside of Islamabad. A recent news report stated that the PAEC may build a large commercial enrichment plant as part of the planned Pakistan Nuclear Power Fuel Complex (PNPFC) in Kundian, near the Chashma power reactors. ${ }^{104,105}$ None of Pakistan's enrichment facilities are currently subject to safeguards. However, the Kyodo report suggests that Pakistan would be willing to submit the new plant at Kundian to safeguards as part of a nuclear deal similar to the U.S.-Indian nuclear deal of 2005. 


\section{CONCLUSION}

Currently, the world enrichment capacity is approximately 53 million kg-separative work units (SWU) per year, with 22 million in gaseous diffusion and 31 million in gas centrifuge plants. The capacity to produce another 23 million SWU/year is under construction or planned for the near future, almost entirely using gas centrifuge separation. Most capacity is concentrated in Russia, the United States, and France, with the three Urenco countries, China and Japan rounding out the bulk of the capacity. Most current and planned enrichment capacity is through gas centrifuge separation. Laser isotope separation may become the technology of choice for new enrichment plants in the future, but current enrichment plants will probably continue operating as long as it is economical to do so.

The idea has been discussed of limiting the spread of enrichment technology to current technology holders, designating a fixed group of enrichment "supplier" countries, in the same way that the list of official nuclear weapon states was established as those countries with nuclear weapons at the first signing of the NPT in 1968. Plans for small enrichment programs by states such as Iran, Brazil, Argentina, South Africa, and Australia may be partially based on the desire to be considered among these "supplier" countries if such a distinction ever becomes official. One possible alternative is the creation of international fuel centers, such as the proposed center at Angarsk in Russia, which would make enrichment services more widely available and assure nuclear fuel supplies for member states.

The demand for new uranium enrichment capacity is expected to increase significantly over the next several decades (Fig. 37). More fuel will be required for the nuclear reactors that are being planned and built, and the current supply of enrichment services will start to decrease as the older GDPs are shut down and alternative sources of fuel, such as through HEU blend-down, are depleted (the U.S.-Russian Megatons-toMegawatts program is expected to end in $\left.2013^{106}\right)$. As demand starts to exceed supply, the economics for investing in new enrichment plants will begin to look more attractive.

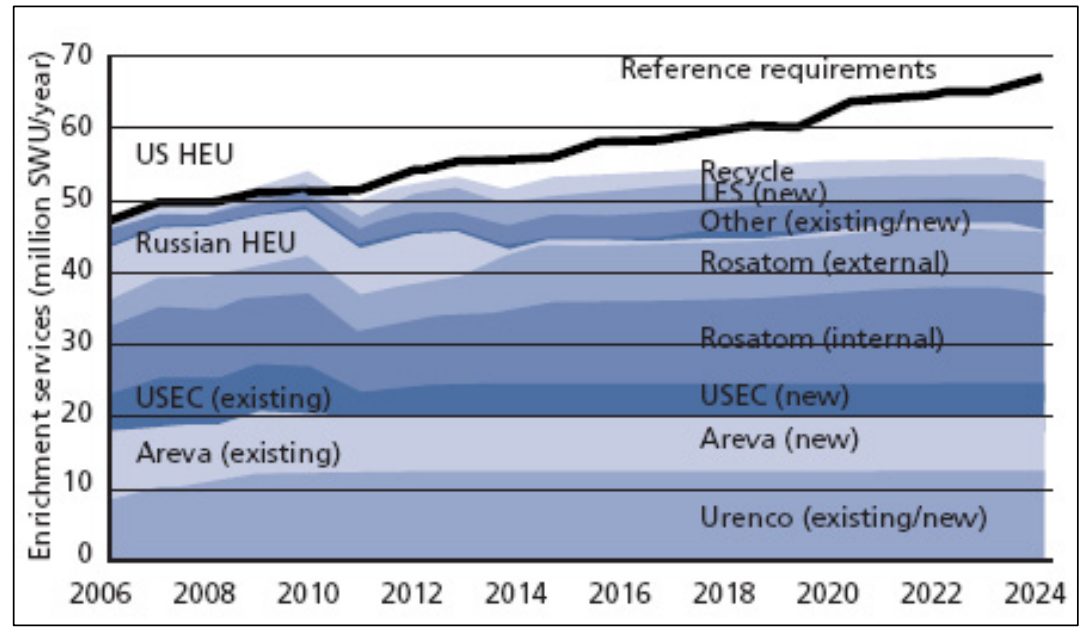

Fig. 37. Projected world enrichment capacity and demand Source: Touch Briefings ${ }^{107}$

The techniques and implementation of safeguards continue to evolve as the IAEA investigates new measures and incorporates new technologies. ${ }^{108}$ The IAEA has worked to expand the scope of its authority by implementing strengthened safeguards and encouraging states to adopt an Additional Protocol. ${ }^{109}$ Advanced safeguards technology such as more effective enrichment monitors, unattended monitoring, and uranium cylinder tracking can assist in better meeting the HSP goals of detecting diversion of declared material at declared facilities; additional measures such as environmental sampling and wide-area monitoring provide some capability to detect undeclared materials and facilities. ${ }^{110,111,112}$ The IAEA will need to use an updated model approach along with advanced technology, an effort that began with the HSP in the early 1980s, to continue to efficiently and effectively apply safeguards as more uranium enrichment facilities come online in more countries. 


\section{REFERENCES}

1 “EURODIF Production.” Areva NC website, 2006, www.areva-nc.com.

2 “U.S.-Russian Megatons to Megawatts Program: About the Program.” USEC, June 2007, www.usec.com.

${ }^{3}$ D.W. Swindle, "Realities of verifying the absence of highly enriched uranium (HEU) in gas centrifuge enrichment plants,” Meeting of the American Physical Society, March 1990, Anaheim, California, K/ITP-327.

4 “Treaty on the Non-Proliferation of Nuclear Weapons.” IAEA, INFCIRC/140, 22 April 1970, www.iaea.org.

${ }^{5}$ Geoff Hiscock, “Australia, China sign uranium deal,” CNN, 2 April 2006, www.cnn.com.

${ }^{6}$ IAEA Nuclear Fuel Cycle Information System (NFCIS), 2007, www-nfcis.iaea.org.

${ }^{7}$ USEC Inc., “USEC Facilities.” www.usec.com/v2001_02/HTML/facilities.asp.

${ }^{8}$ D.A. Waters, “The American Gas Centrifuge: Past, Present, and Future.” USEC., Separation Phenomena in Liquids and Gases Workshop, 13 October 2003.

${ }^{9}$ USEC Inc., “USEC Inc. suspends AVLIS technology development.” Press Release, 9 June 1999, www.usec.com/v2001_02/HTML/News_Archive.asp.

${ }^{10}$ Dan Charles, “Spinning a nuclear comeback.” Science 315, pp. 1782-1784, 30 March 2007.

${ }^{11}$ USEC Inc., “USEC updates progress on Lead Cascade, American Centrifuge Project.” Press Release, 1 August 2007, www.usec.com/v2001_02/HTML/News_Archive.asp.

12 “Louisiana Energy Services (LES) Gas Centrifuge Facility,” NRC New Fuel Facility Licensing, 31 August 2007, www.nrc.gov/materials/fuel-cycle-fac/lesfacility.html.

${ }^{13}$ Urenco, “National Enrichment Facility,” www.nefnm.com.

14 "NRC issues license to Louisiana Energy Services for gas centrifuge uranium enrichment plant in New Mexico,” NRC Press Release, 23 June 2006, www.nrc.gov.

${ }^{15}$ Areva, "Expanding the U.S. nuclear infrastructure by building a new uranium enrichment facility," Pre-application meeting with the U.S. NRC, 21 May 2007, www.nrc.gov.

${ }^{16}$ GE Energy, “GE signs agreement with Silex Systems of Australia to develop uranium enrichment technology,” Press Release, 22 May 2006, www.ge-energy.com.

${ }^{17}$ GE Energy, “GE, Hitachi sign formation agreement for global nuclear energy business alliance,” Press Release, 16 May 2007, www.ge-energy.com.

18 Silex Systems Ltd., “About Silex,” “Company History,” and “Announcements,” www.silex.com.au.

${ }^{19}$ Steven Dolley, “Exelon, Entergy express support for GE-Hitachi laser enrichment.” Nuclear Fuel 32, No. 21, 8 October 2007. 
${ }^{20}$ IAEA NFCIS, 2007.

21 “Our Sites: Capenhurst.” UK Nuclear Decommissioning Authority, www.nda.gov.uk.

${ }^{22}$ Urenco, “Urenco Capenhurst,” www.urenco.com.

23 “Summary report: centrifuge enrichment plant safeguards at Urenco plants.” U.S. DOE and Urenco officials, 1 October 2004.

${ }^{24}$ Oleg Bukharin, “Russia’s gaseous centrifuge technology and uranium enrichment complex.” Program on Science and Global Security, Woodrow Wilson School of Public and International Affairs, Princeton University, January 2004.

${ }^{25}$ Peter Diehl, “Re-enrichment of West European depleted uranium tails in Russia,” Ecodefense Russia, 2004.

${ }^{26}$ Mark Hibbs et al., “Russia to stop commercial tails re-enrichment.” Nuclear Fuel, 31, No. 16, 31 July 2006.

27 “First uranium enrichment center to open in Siberia - Kiriyenko.” RIA Novosti, 15 July 2006, http://en.rian.ru/russia/20060715/51394941.html.

${ }^{28}$ D.Albright, F. Berkhout, and W. Walker, "Inventories of highly enriched uranium in the nuclear weapon states.” In Plutonium and Highly Enriched Uranium 1996: World Inventories, Capabilities and Policies, SIPRI, 1996, www.sipri.org.

29 “Disarmament champion.” News from France, French Embassy Press and Information Service, Vol. 96-4, 1 March 1996, www.info-france-usa.org.

${ }^{30}$ Ann MacLachlan, “HEU production ends at Pierrelatte.” Nuclear Fuel 21, No. 15, 15 July 1996.

${ }^{31}$ IAEA NFCIS, 2007.

${ }^{32}$ Areva, “Uranium products and services: Enrichment,” www.us.areva-nc.com.

${ }^{33}$ Ron Witzel, “Enrichment Supply Assessment.” Longenecker and Associates, May 2007.

${ }^{34}$ Areva, “AREVA and URENCO announce the creation of the Joint Venture ETC," and "The way is open for the construction of the new Georges Besse II enrichment plant,” Press Releases, 3 July 2006, www.areva.com.

${ }^{35}$ Areva, Pre-application meeting with the U.S. NRC, 21 May 2007.

${ }^{36}$ Areva, “Georges Besse II: A new era for enrichment,” Areva brochure, May 2007, www.areva.com.

37 SIPRI, 1996.

${ }^{38}$ IAEA NFCIS, 2007.

${ }^{39}$ Bowen et al., "Nuclear- and missile-related trade and developments for selected countries, MarchJune 1999: China.” The Nonproliferation Review, Fall 1999, p.179-199.

${ }^{40}$ Bukharin, 2004. 
${ }^{41}$ A. Panasyuk et al., "Tripartite enrichment project: safeguards at enrichment plants equipped with Russian centrifuges,” IAEA Symposium on International Safeguards, Vienna, 2001, IAEA-SM367/8/02. www-pub.iaea.org.

${ }^{42}$ Urenco, “Extending Our Global Reach: Annual Report and Accounts 2006,” www.urenco.com.

${ }^{43}$ Urenco, “Uranium enrichment plant Gronau: site history.” www.urenco.com.

${ }^{44}$ B.G. Dekker and E.F.M. Steinebach, "The development and experience of safeguards at the Dutch and German uranium enrichment plants (URENCO)," Transactions of the American Nuclear Society, $3^{\text {rd }}$ International Conference on Facility Operations-Safeguards Interface, San Diego, 1987, Vol. 55, Supl. 1, p.12.

${ }^{45}$ J.K. Aaldijk et al., "Gamma techniques for IAEA safeguards at centrifuge enrichment cascades.” Transactions of the American Nuclear Society, $3^{\text {rd }}$ International Conference on Facility Operations-Safeguards Interface, San Diego, 1987. Vol. 55, Supl. 1, p.13.

${ }^{46}$ S. Yonekawa et al., "Current status and future plan of uranium enrichment technology,” Transactions of the American Nuclear Society, 1994 Winter Meeting, Washington DC., Vol. 71, p.77.

${ }^{47}$ Masato Hori, “Centrifuge dismantling at Uranium Enrichment Facility,” JNC, IAEA Technical Meeting on Techniques for the Verification of Enrichment Activities, Vienna, April 2005.

${ }^{48}$ IAEA NFCIS, 2007.

${ }^{49}$ Mark Hibbs, “Japan revised, slimmed down its carbon fiber centrifuge,” Nuclear Fuel 32, No. 11, 21 May 2007.

${ }^{50}$ JNFL, “Our Business: Uranium Enrichment,” www.jnfl.co.jp/english/uranium.html.

${ }^{51}$ JNFL, "Start of the cascade test at the Uranium Enrichment Plant,” Press Release, 2 April 2007, www.jnfl.co.jp.

${ }^{52}$ M. Hayashi et al., "Present status of safeguards implementation in Japan,” IAEA Symposium on International Safeguards, Vienna, 1994, IAEA-SM-333/39. www-pub.iaea.org.

${ }^{53}$ Australian Nuclear Science and Technology Organisation, "Clarification on ABC 7.30 Report's uranium enrichment story,” Media Statement, 15 June 2007, www.ansto.gov.au.

${ }^{54}$ Jodie Evans and Russell Leslie, “Australia’s gas centrifuge program and safeguards related research,” ASNO, presentation to the IAEA Technical Working Group on Enrichment, Vienna, 18-22 May 2005.

${ }^{55}$ John Carlson, "The prospects for uranium enrichment in Australia - correcting the record,” Media Release, Australian Department of Foreign Affairs and Trade, 18 June 2007, www.dfat.gov.au.

56 “Project and Operational Update,” Silex Systems Limited, 30 August 2007, www.silex.com.au.

${ }^{57}$ ABACC, www.abacc.org.

${ }^{58}$ O.M. Guidicini et al., "Development of low-level environmental sampling capabilities for uranium at Brazilian and Argentine laboratories by ABACC,” ABACC, 2003, www.abacc.org.

${ }^{59}$ O.M. Guidicini et al., "The development of low-level measurement capabilities for total and isotopic 
uranium in environmental samples at Brazilian and Argentine laboratories by ABACC," Journal of Nuclear Materials Management 33, No. 4, pp. 4-12, Summer 2005.

${ }^{60}$ H.E. Vicens, M.A. Marzo, and V.E. Nunes, "Considerations on safeguards approach for small centrifuge enrichment facilities,” ABACC, 2004, www.abacc.org.

${ }^{61}$ Mohamed El Baradei, "Introductory Statement to the Board of Governors," Statement by the IAEA Director General to the Board of Governors, 13 September 2004, www.iaea.org.

${ }^{62}$ Mark Hibbs, “77\% U-235 was peak enrichment reported to IAEA by South Korea.” Nuclear Fuel 29, No. 20, p. 7, 27 September 2004.

${ }^{63}$ IAEA NFCIS.

${ }^{64}$ Sharon Squassoni and David Fite, "Brazil as litmus test: Resende and restrictions on uranium enrichment,” Arms Control Today, October 2005.

${ }^{65}$ Steve Kingstone, “Brazil joins world’s nuclear club,” BBC News, 6 May 2006.

${ }^{66}$ Mark Hibbs, "Bearing design prompted Brazil to withhold centrifuge data from IAEA," Nuclear Fuel 29, No. 25, p. 1, 6 December 2004.

${ }^{67}$ Squassoni and Fite, 2005.

68 "In message to the Navy, Lula defends Brazilian nuclear program,” Statements by the Brazilian President, 11 June 2007, www.presidencia.gov.br/ultimas_noticias.

${ }^{69}$ J.M. Whitaker. "Efforts to develop, test, and evaluate new techniques for strengthening international safeguards." 46 ${ }^{\text {th }}$ INMM Annual Meeting, Phoenix, AZ, 14 July 2005.

70 "MinPlan in the News," Statements by the Argentinean Minister of Planning, 23 August 2006, www.minplan.gov.ar.

${ }^{71}$ AECL, “AECL signs agreement with Argentina to enter into negotiations for new CANDU unit," Press Release, 27 July 2007, www.aecl.ca.

72 “South Africa’s Nuclear Weapons Program: Putting Down the Sword,” Nuclear Weapon Archive, 2001, www.nuclearweaponarchive.org.

73 “South Africa's Nuclear Weapons Program: An Annotated Chronology,” Monterey Institute of International Studies Center for Nonproliferation Studies, $\underline{\text { cns.miis.edu. }}$

${ }^{74}$ Adolf von Baeckmann et al., "Nuclear verification in South Africa," IAEA Bulletin, 37-1, f40.iaea.org/worldatom/Periodicals/Bulletin/.

${ }^{75}$ South African Department of Minerals and Energy, "Keynote address delivered by the Minister of Minerals and Energy at the launch of the SA Young Nuclear Professional Society," 25 August 2006, www.dme.gov.za.

${ }^{76}$ South African Department of Minerals and Energy, "Nuclear Energy Policy and Strategy for the Republic of South Africa: Draft for Public Comment,” July 2007, www.dme.gov.za.

${ }^{77}$ David Albright, "Iraq's programs to make highly enriched uranium and plutonium for nuclear weapons prior to the Gulf War,” Institute for Science and International Security, October 2002, 
www.isis-online.org.

${ }^{78}$ Albright, 2002.

79 Jacques Baute, “Timeline Iraq.” IAEA Bulletin 46-1, pp. 64-68, June 2004.

80 “Iraq Nuclear Chronology,” Nuclear Threat Initiative Country Profiles, www.nti.org.

81 “In Focus: IAEA and Libya,” IAEA News Centre, www.iaea.org/NewsCentre.

${ }^{82}$ George W. Bush, "President announces new measures to counter the threat of WMD," Remarks by the President of the United States, Washington DC, 11 February 2004, www.whitehouse.gov.

${ }^{83}$ IAEA, “Implementation of the NPT Safeguards Agreement of the Socialist People’s Libyan Arab Jamahiriya,” Reports by the Director General, GOV/2004/12, 20 February 2004; GOV/2004/59, 30 August 2004.

${ }^{84}$ Frank Munger and Richard Powelson, “Secret shipment at Y-12,” Knoxville News Sentinel, 28 January 2004.

85 ““'Out of Sight’ Missions,” Oak Ridge National Laboratory Review, Vol. 39, No.1, 2006.

86 “Iran Nuclear Chronology,” Nuclear Threat Initiative Country Profiles, www.nti.org.

${ }^{87}$ David Albright and Corey Hinderstein, “The Iranian gas centrifuge uranium enrichment plant at Natanz,” Institute for Science and International Security, 14 March 2003, www.isisonline.org/publications/iran/.

88 "Implementation of the NPT Safeguards Agreement in the Islamic Republic of Iran,” IAEA Director General's report to the Board of Governors, GOV/2007/48, 30 August 2007.

${ }^{89}$ David Albright and Jacqueline Shire, “IAEA safeguards report on Iran: limited progress on enrichment.” Institute for Science and International Security Issue Brief, 30 August 2007, www.isis-online.org/publications/iran/.

${ }^{90}$ Houston Wood, “Analysis of the proposed gas centrifuge plant at Natanz," $48^{\text {th }}$ Annual Meeting of the INMM, Tucson, AZ, July 2007.

${ }^{91}$ Paul Kerr, “N. Korea’s uranium-enrichment efforts shrouded in mystery,” Arms Control Today, May 2003, www.armscontrol.org.

92 “U.S., North Korea conclude talks on ties,” Morning Edition, National Public Radio, 7 March 2007, www.npr.org.

93 Paul Kerr, “Doubts rise on North Korea’s uranium-enrichment program,” Arms Control Today, April 2007, www.armscontrol.org.

${ }^{94}$ S.S. Harrison, “Did North Korea cheat?” Foreign Affairs, January/February 2005, www.foreignaffairs.org.

${ }^{95}$ M.B. Reiss and R. Gallucci, “Dead to Rights,” Foreign Affairs, March/April 2005, www.foreignaffairs.org.

${ }^{96}$ David Albright, “North Korea’s alleged large-scale enrichment plant: Yet another questionable 
extrapolation based on aluminum tubes,” Institute for Science and International Security, 23 February 2007, www.isis-online.org.

${ }^{97}$ Carl Levin, "Levin writes to Rice, Gates on North Korea," Senator Carl Levin - Press Office, 2 March 2007 www.senate.gov/ levin.

98 “Inside Dimona, Israel's nuclear bomb factory,” "Revealed - The secrets of Israel's nuclear arsenal,” and "How the experts were convinced," The Sunday Times, London, 5 October 1986.

${ }^{99}$ David K. Shipler, “A-Arms capacity of Israelis: A topic rich in speculation,” New York Times, 29 October 1986.

${ }^{100}$ Mark Hibbs, “India to equip centrifuge plant with improved rotor assemblies," Nuclear Fuel 22, No. 24, p. 7, 1 December 1997.

101 “India Nuclear Facilities,” Nuclear Threat Initiative Country Profiles, www.nti.org.

102 “Urenco centrifuge technology and proliferation,” Urenco, National Enrichment Facility Information Sheet, 9 March 2004, www.nefnm.com.

${ }^{103}$ Andreas Persbo, “Entering Khan’s little den.” Verification, 28 March 2007, verificationthoughts.blogspot.com.

104 “Pakistan to set up $2^{\text {nd }}$ uranium enrichment plant,” Kyodo News, 22 August 2007, www.kyodo.co.jp.

${ }^{105}$ Ihtasham ul Haque, “Plan for enhanced use of N-energy.” DAWN Internet Ed., 8 August 2007. www.dawn.com.

106 “U.S.-Russian Megatons to Megawatts Program: About the Program.” USEC, June 2007. www.usec.com.

${ }^{107}$ T.B. Meade and M.H. Schwartz. "The market for uranium enrichment services.” Touch Briefings' Nuclear Energy Review 2007, pp. 23-24, June 2007. www.touchbriefings.com.

108 "Nuclear Nonproliferation: IAEA has strengthened its safeguards and nuclear security programs, but weaknesses need to be addressed.” U.S. Government Accountability Office, GAO-06-93, October 2005.

109 "Strengthening the effectiveness and improving the efficiency of the safeguards system including implementation of Additional Protocols.” IAEA Director General's Report to the $51^{\text {st }}$ General Conference, GC(51)/8, 23 July 2007. www.iaea.org.

110 "Final Report of the Technical Meeting on Techniques for the Verification of Enrichment Activities.” Vienna, April 2005.

${ }^{111}$ J.M. Whitaker et al. "Verification options for gas centrifuge enrichment plants.” ORNL/TM2005/63, September 2005.

${ }^{112}$ N. Khlebnikov et al. "Novel technologies for the detection of undeclared nuclear activities.” IAEACN-148/32, February 2007. 